\title{
Market Channels of Technology Startups that Internationalize Rapidly from Inception
}

\author{
by
}

Simar Yoos

A thesis submitted to the Faculty of Graduate and Postdoctoral Affairs in partial fulfillment of the requirements for the degree of

Master of Applied Science

In

Technology Innovation Management

Carleton University

Ottawa, Ontario

(C) 2013, Simar Sanio Yoos 
Library and Archives

Canada

Published Heritage

Branch

395 Wellington Street

Ottawa ON K1A ON4

Canada
Bibliothèque et

Archives Canada

Direction du

Patrimoine de l'édition

395 , rue Wellington

Ottawa ON K1A ON4

Canada
Your file Votre référence

ISBN: $978-0-494-94270-3$

Our file Notre référence

ISBN: $978-0-494-94270-3$
NOTICE:

The author has granted a nonexclusive license allowing Library and Archives Canada to reproduce, publish, archive, preserve, conserve, communicate to the public by telecommunication or on the Internet, loan, distrbute and sell theses worldwide, for commercial or noncommercial purposes, in microform, paper, electronic and/or any other formats.

The author retains copyright ownership and moral rights in this thesis. Neither the thesis nor substantial extracts from it may be printed or otherwise reproduced without the author's permission.
AVIS:

L'auteur a accordé une licence non exclusive permettant à la Bibliothèque et Archives Canada de reproduire, publier, archiver, sauvegarder, conserver, transmettre au public par télécommunication ou par l'Internet, prêter, distribuer et vendre des thèses partout dans le monde, à des fins commerciales ou autres, sur support microforme, papier, électronique et/ou autres formats.

L'auteur conserve la propriété du droit d'auteur et des droits moraux qui protege cette thèse. $\mathrm{Ni}$ la thèse ni des extraits substantiels de celle-ci ne doivent être imprimés ou autrement reproduits sans son autorisation.
In compliance with the Canadian Privacy Act some supporting forms may have been removed from this thesis.

While these forms may be included in the document page count, their removal does not represent any loss of content from the thesis.
Conformément à la loi canadienne sur la protection de la vie privée, quelques formulaires secondaires ont été enlevés de cette thèse.

Bien que ces formulaires aient inclus dans la pagination, il n'y aura aucun contenu manquant. 


\begin{abstract}
The study of technology startups that internationalize rapidly from inception has increased in recent years. However, little is known about their channels to market, and few of these studies are related to challenges facing born globals when making marketing channel selection decisions. This study addresses a gap in the "born global" literature by examining the channels used by 21 startups during their first three years after inception, as well as the programs they used to support their channel partners and customers. The study informs entrepreneurs who need to exploit global opportunities about decisions regarding channel market selection made by entrepreneurs who launched born global companies. The 21 startups examined were found to combine the use of the Internet with: i) a relationship with a multi-national, ii) distributors, iii) re-sellers or iv) a direct sales force. They also delivered programs to support partners and customers that focused on communications, alliance and network development, education, marketing and promotion and financial incentives.
\end{abstract}




\section{Acknowledgements}

"There are very few human beings who receive the truth, complete and staggering, by instant illumination. Most of them acquire it fragment by fragment, on a small scale, by successive developments, cellularly, like a laborious mosaic."

(Anaïs Nin)

A master thesis is an exercise in solitude. It is possibly the first chance a researcher has to prove his maturity, through his ability to persist and complete a task, and the capacity to do a job while supervised. Only a master student knows how difficult this is, and if what he did is worthwhile. Interestingly, when looking at my path I not only see the loneliness but, paradoxically, the people who shared the journey with me. There were many who assisted me at crucial moments to complete this laborious mosaic of a thesis, and it those I wish to thank now.

First, my teacher and supervisor Tony Bailetti, admirable for so many things he does for his students, but mostly for his simplicity of instruction and clarity of vision. Without him, this thesis simply would not exist. To extend my gratitude to Tony, I would like to use the words of another teacher, Roland Christensen of Harvard University. He said that teachers, ultimately, not only teach what they know, but what they are. And that, by the reciprocity between teaching and learning, teachers can share in the success of their students. Tony surely shares any success I have achieved, and perhaps even that I will achieve in the future. Though he gave me the complete theoretical background of Born. Global Business, I most appreciated his many natural human qualities: persistence, integrity, affection and generosity. 
I also wish to thank the teachers Michael Weiss, Mika Westerlund and Steven Muegge, for accepting the invitation to be part of the process, for their generous and timely contributions to this work, and for serving as models and inspirations through their academic careers. And, of course, Chris McPhee, the Editor in Chief of the TIM Review for his invaluable support and encouragement.

This list could hardly include all those who are worthy, so my gratitude to the many others who were always there for me ... even if it was just to ask, "Have you finished your thesis?" every time they saw me.

Finally, a master thesis requires a degree of individuality. We must read everything and refer to all, but the final result depends on our ability to understand our methodological choices, and our intellectual honesty. I believe a master thesis is also the result of who we are, or, as beautifully put by Fernando Pessoa:

"Follow your destiny, watering your plants, love your roses.

The rest is beyond the shadow of trees. The reality is always more or less what we want. Only we are always equal to ourselves." 


\section{Table of Contents}

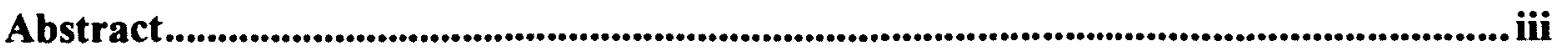

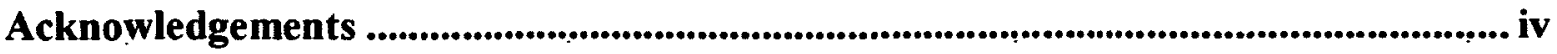

Table of Contents ............................................................................................................... vi

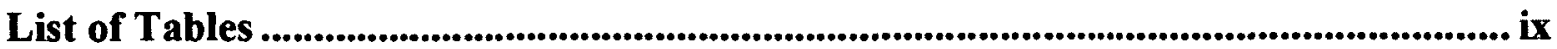

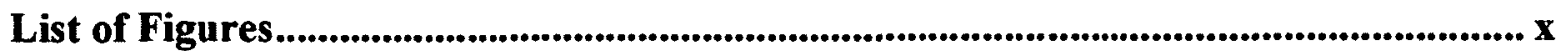

1 Chapter: Introduction ................................................................................................................... 11

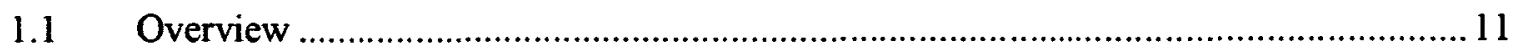

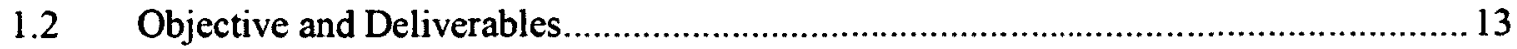

$1.3 \quad$ Relevance

1.4 Contribution

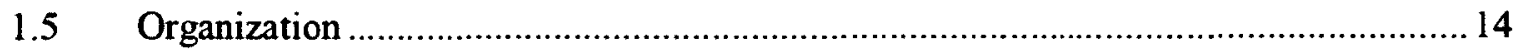

2 Chapter: Literature Review........................................................................................ 16

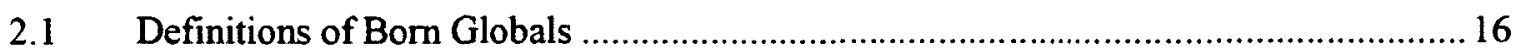

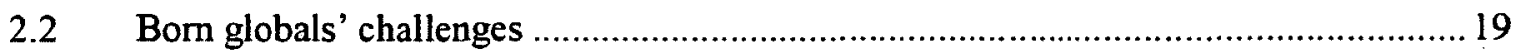

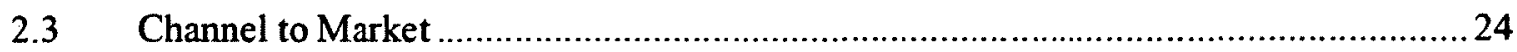

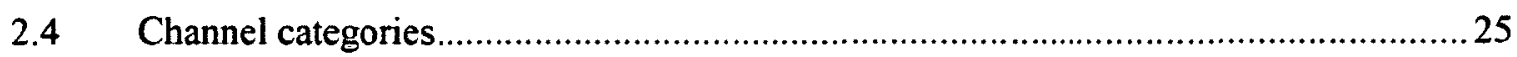

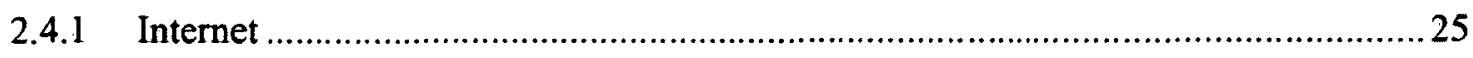

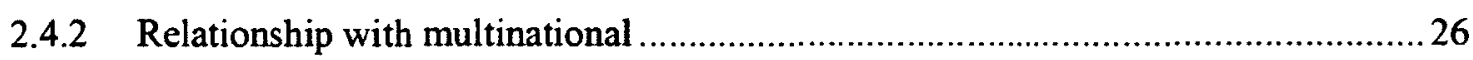

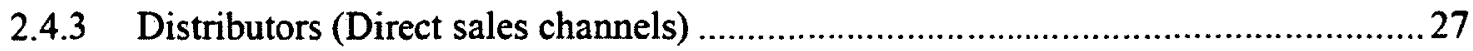

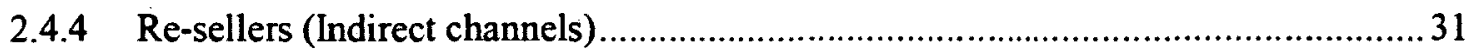

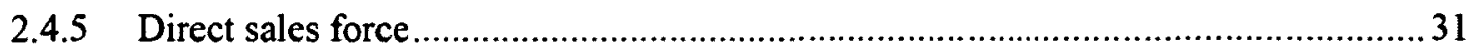

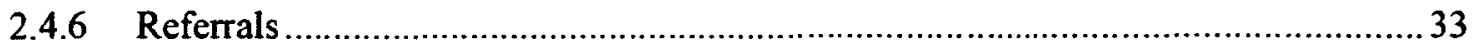

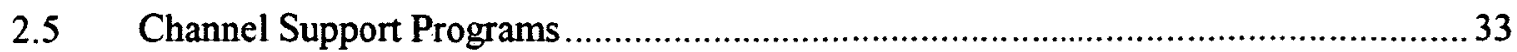

2.5.1 Network and Alliances as channels to Market …….............................................. 35 
3 Chapter: Research Steps and Methodology ...............................................41

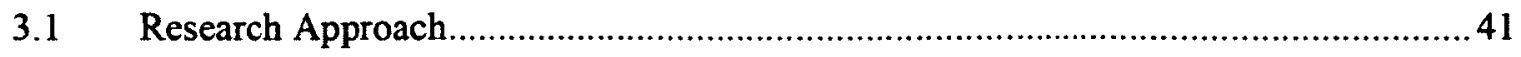

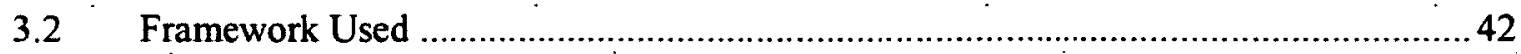

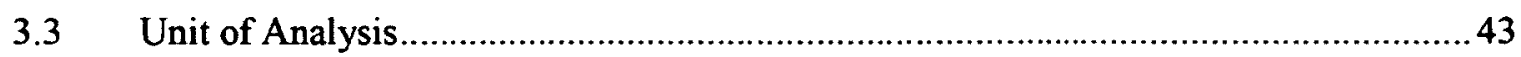

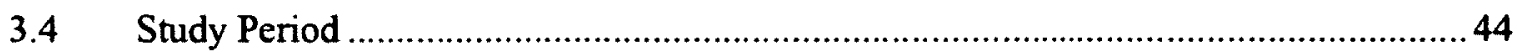

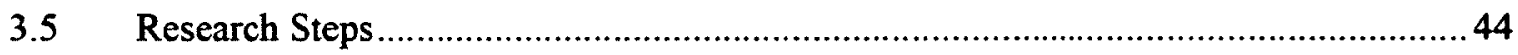

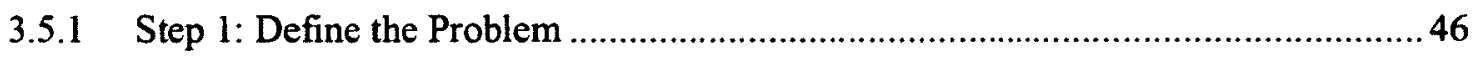

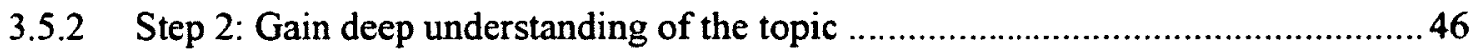

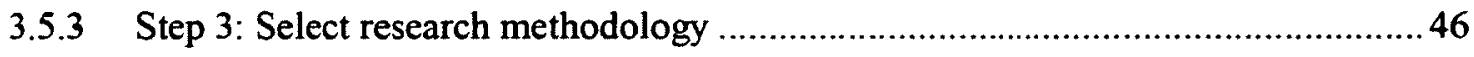

3.5.4 Step 4: Define sample criteria and population of the sample $\ldots \ldots \ldots \ldots \ldots \ldots \ldots \ldots \ldots \ldots . . . . . \ldots 7$

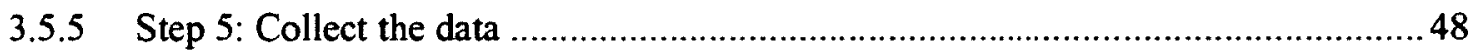

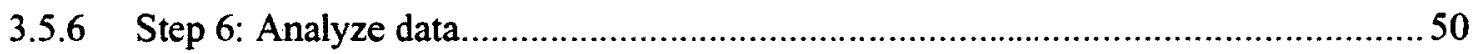

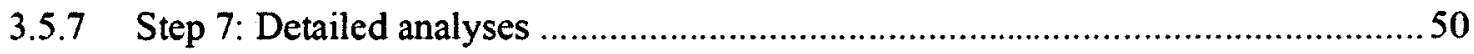

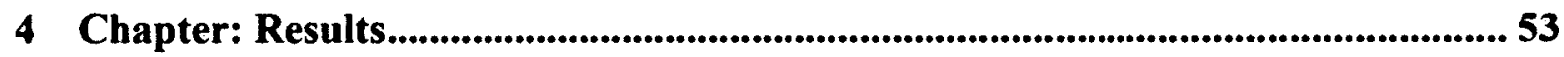

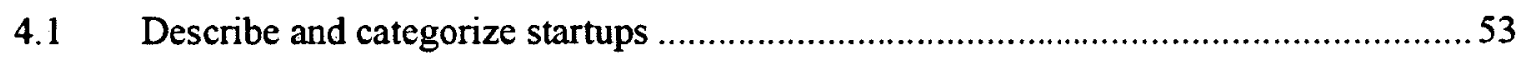

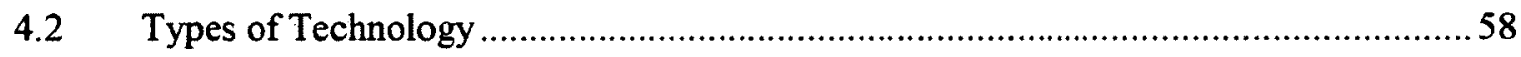

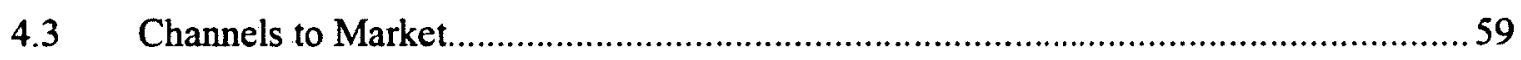

4.4 Partner Programs and Website Features Used to Support Them ............................... 64

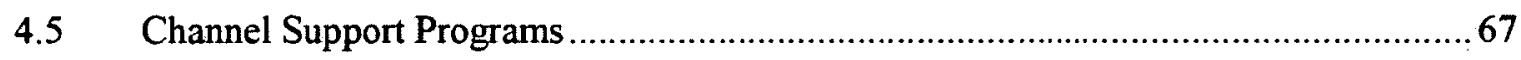

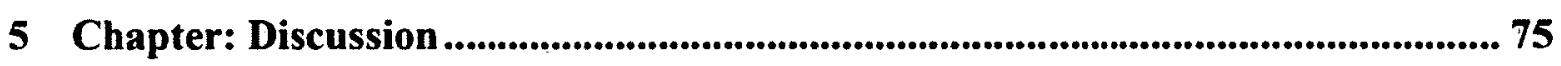

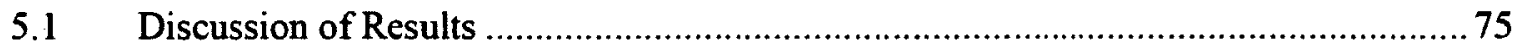

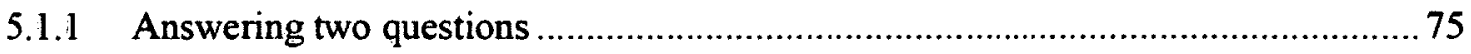

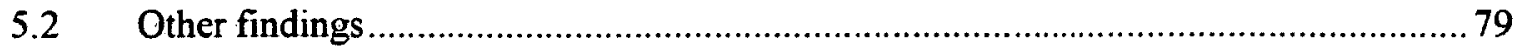

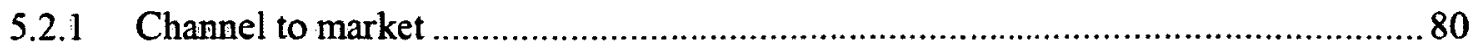




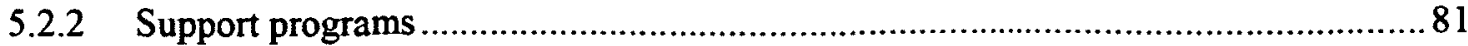

6 Chapter: Conclusion, Limitations and Future research ..................................... 83

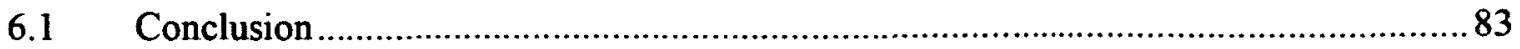

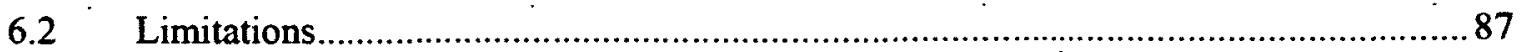

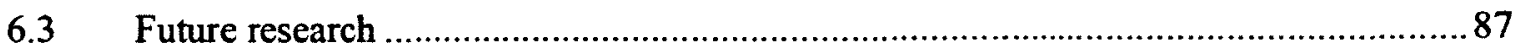




\section{List of Tables}

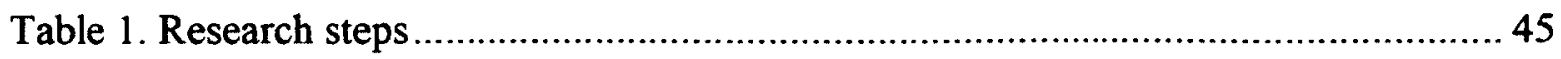

Table 2. The 21 technology firms in the sample .......................................................5

Table 3. Classes of startups by use of technology to capture value ................................ 58

Table 4. Channels to market used by twenty firms in the sample ................................ 59

Table 5. Combinations of Channels to Market Used by 21 Companies in the Sample... 63

Table 6. Features on the websites of the 21 technology startups that supported channel

partners

Table 7. Core elements of the Channel Support Programs ................................................6 68

Table 8. Programs to support channel partners and customers delivered by 21 startups . 73 


\section{List of Figures}

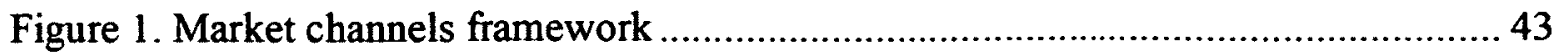

Figure 2. Startups in the sample by region where founded from 2002 to $2009 \ldots \ldots \ldots \ldots . . .56$

Figure 3. Born global startups' offer type ...................................................... 57

Figure 4. Channel Combinations used by Born Globals in the Sample ......................62

Figure 5. Simplified support channel partners ................................................... 85 


\section{"1 Chapter: Introduction}

Chapter 1 is organized into five sections. Section 1.1 provides an overview of the research, Section 1.2 describes the objective and deliverables of the research, Section 1.3 identifies the groups that may find this research relevant, Section 1.4 describes the contribution made by this research and Section 1.5 outlines how the thesis is organized.

\subsection{Overview}

A born global is a small or medium-size enterprise (SME) venture that is launched to exploit a global niche from the first day of operations (Kirpalani \& Gabrielsson, 2012). Born globals can operate in the high-tech (Preece at al., 1999) and software (Bell, 1995) fields, as well as fields such as innovative designs (Falay et al., 2007), high-quality services and sophisticated systems (Luostarinen \& Gabrielsson, 2004). Born globals can also be found in the traditional food, apparel, footwear, furniture and other low-tech industries (Gabrielsoon et al., 2008).

Scholars have used different names and definitions to refer to born globals. In their review, Luostarinen and Gabrielsson (2004) found that the term "born global is used to refer to: (a) deviations, inconsistencies and variations to the stage models of internationalization, (b) new technology-based firms, (c) high-technology start-ups, (d) born internationals, (e) international new ventures, (f) global start-ups, (g) instant internationals and, (h) global, knowledge-intensive firms, among others. There is a lot of research about born globals explaining what they are, but nothing about the channels to market they use. This research addresses a gap in the born-global literature, by 
identifying: i) the channels to market used by 21 technology startups that internationalized rapidly and, ii) the programs they delivered to support their channel partners (i.e. support programs)

For the purpose of this research, channel partners are the multinational firms, distributors and re-sellers that are linked with the startups in the first three years of their internationalization process. The intention of this work is to understand which partners the startups used, how they used channels to market, and the programs that they delivered to support their channel partners.

After researching the born global literature, it is clear that it does not include channels to market and support programs. There are many studies about bom globals existence and characteristics, but none explain how they internationalize rapidly upon or shortly after inception. The literature also does not discuss which channel configurations and support program born globals used. While the literature does examine the differences between the internationalization processes of born globals and those of traditional businesses, the literature does not focus on channels to market.

This research identifies the channel to market configurations used by startups that internationalized at inception, and the corresponding support programs. It also identifies the web features used to support channels. 


\subsection{Objective and Deliverables}

The objective of this research is to identify the: i) configurations of channels to market used'by technology startups that internationalized rapidly from inception and ii) programs that they delivered to support their channel partners (i.e., support programs).

The four deliverables of this research are:

- Inventory of the configuration of market channels and corresponding support programs used by technology startups that internationalized rapidly from inception.

- Factors that influence startups to select a specific combination of channels to market

- Features of websites that startups used to support their channels partners.

- Lessons learned from carrying out this research that can be used by entrepreneurs who wish to launch and grow technology companies that internationalize rapidly from inception.

\subsection{Relevance}

This research is relevant to entrepreneurs who need to design market channels to exploit global opportunities because it identifies the decisions made by other entrepreneurs who launched born global companies. Providers of knowledge services and risk capital to these entrepreneurs may also find this work relevant. 
Researchers will find this research relevant because it fills a gap that exists in the born global literature. Little is known about the market channels born global firms use at an early stage of their growth.

This research is also relevant to mentors, consultants and providers of incubation services. They can apply the results and lessons learned from this research to advise entrepreneurs.

Finally, this research is relevant to academic programs and economic development organizations that lead the launch and growth of a large number of born globals to create knowledge jobs in the region.

\subsection{Contribution}

This research informs entrepreneurs who wish to launch and grow born global companies about the combinations of channels to market and their support programs that have been used by other entrepreneurs. The major benefit of this contribution is that it will reduce the time to make channel related decisions and reduce costly mistakes.

\subsection{Organization}

The thesis is organized into six chapters. Chapter 1 is the introduction. Chapter 2 provides a review of the relevant literature on born global businesses and channels to market. Chapter 3 describes the method used to carry out this research. Chapter 4 provides the results of the study and Chapter 5 discusses these results. Finally, Chapter 6 
provides the conclusions and limitations of this research and provides suggestions for future research. 


\section{Chapter: Literature Review}

Chapter 2 provides a review of the literature relevant to this research. Section 2.1 provides a review of the challenges of born globals. Section 2.2 describes the channels to market literature. Section 2.3 reviews the channel support programs literature. Section 2.4 provides definitions of born globals. Section 2.5 identifies the lessons learned from the literature review.

\subsection{Definitions of Born Globals}

Oviatt and McDougall (1994, p.49) defined born globals as organizations that, from inception, aggressively seek to derive vital benefits from the use of resources and the sale of outputs in multiple countries. Born globals pursue an imaginative vision of becoming global and globalize quickly from inception, without a preceding long-term domestic or internationalization period (Luostarinen \& Gabrielsson, 2004).

Two distinct groups of exporters, "traditional business" or "Born Global," were identified according to the following characteristics (Rennie, 1993):

- Traditional business: This group is domestically based and follows the traditional export model (in stages). Its core businesses are well established, with strong financing, high capability, and a solid product portfolio. Once they reach sustainable operations in their home markets, they concentrate on growing their potential exports, although the main focus remains the market household. On average, such companies began exporting 27 years after inception, and the ratio of exports to total sales was $20 \%$. 
- Born Global: This group starts exporting on average only two years after inception, and $76 \%$ of total sales are through exports. They invoice an average of one quarter of the total revenue of a traditional exporter (including domestic sales). They tend to "own" consumers, since they understand and meet the needs of a particular group of consumers better than anyone else globally.

Gabrielsson (2005, p.200) stated that "Born Globals can be defined various ways, ranging from strict to relatively loose." Over time, the literature has accumulated different definitions and characterizations for Born Globals, including the following:

- Smaller companies and entrepreneurs that internationalized at or soon after their inception. Their main competitive advantage is usually connected to expertise that they use to explore the dynamics of an environment that is increasingly global (Bell, McNaughton and Young, 2001);

- Companies that seek competitive advantage through the use of resources and sales to multiple countries since their birth, via a proactive international strategy (Oviatt and McDougall, 1994);

- Entrepreneurial initiatives and smaller companies that target the international market early on, and for whom the traditional models of widespread international business fail to explain their existence and behavior (McDougall, Shane and Oviatt, 1994);

- Companies operating in limited time and space, that allows or forces them to assume a geographical global scope from birth (Zucchella, 2002); 
- Firms that follow a vision to go global from their inception, and globalize more quickly than domestic enterprises dedicated to the process of internationalization (Gabrielsson, 2005).

Criticisms of the diverse definitions of born globals were raised by Gabrielsson, Kirpalani, Dimitratos, Solberg and Zucchella (2008). And Luostarinen and Gabrielsson (2006) stated that a company should derive at least $50 \%$ of its gross sales from outside its continent in a specific number of years to qualify as a born global.

Gabrielsson, Kirpalani, Dimitratos, Solberg and Zucchella (2008) also suggested that the following criteria are required for a company to be a born global: a) it must be a small to medium sized company with a global vision from inception; b) its merchandise needs to be unique and have global market potential; c) it must be an independent firm; and, d) it should have the capability of accelerated internationalization. These criteria were intended to broaden the definition of born globals, and take into consideration, "that the context of born globals varies greatly with regard to the home market potential, product, and export market receptivity." Hence, "absolute figures and percentages may well vary from one setting to another" (Gabrielsson, Kirpalani, Dimitratos, Solberg, \& Zucchella, 2008, p. 400). 


\subsection{Born globals' challenges}

Typically, born global firms lack the managerial and financial resources required to internationalize rapidly from inception (Luostarinen \& Gabrielsson, 2004). Startups need to establish credibility before they can raise the resources required to operate globally.

Born globals have different challenges for internationalization than traditional businesses. In their study of 24 born globals, Knight and Cavusgil (2005) identified these challenges: being smaller and having less expertise, vulnerable networks, and insufficient human resource administration skills.

One important challenge confronting born globals is the distinction between them and established multinational corporations (MNCs). To recognize the differences, one must be aware of the main characteristics of MNCs. According to Rennie (1993), MNCs are first strongly established domestically, and then they internationalize. They're supported in internationalization course of by their brand name in international market, strong monetary capability, skillful human resource management, and effectively constructed product portfolio. That is why historically it was argued that large organizations, with nicely developed businesses within the domestic market, are anticipated to take larger steps in the technique of internationalization (Johnson \& Vahlne, 1977).

This suggests that large MNCs have a competitive advantage over born global SMEs. However, in the last few years born globals have shown that they can prosper. Oviatt and McDougall (1994) provided empirical evidence that born global SMEs are growing 
worldwide, although they have less internationalization advantages than MNCs. The essential difference is that born global SMEs initiate internationalization at the start of business, whereas MNCs approach internationalization after successfully dealing with domestic markets. This actually gives born globals specific advantages over MNCs, since they take international markets into account upon inception.

Born globals face both internal and external challenges, which have been identified by different researchers. Rennie (1993) stated that the challenges faced by born global SMEs are different than those encountered by large firms. The principle challenges confronted by born global result from a lack of resources, management issues, limited access to financing, less global market knowledge and a lack of innovation. Without adequate financing they are unable to hire competitive staff, which leads to inferior human resources and less critical market information. Limited innovation can also be a result of limited finances, as they are unable to focus on research and improvements in order to establish progressive business processes or innovation. These types of challenges are not normally faced by larger companies, since they have access to resources and financing, strong management skills, market knowledge and well managed networks.

Rennie (1993) studied the lack of innovation faced by born globals. Lack of innovation is rooted in inadequate financing and limited human resource management skills. Innovation requires employees and consultants who can analyze and create new ideas that can differentiate their product or service from their competitors. Entrepreneurs often do 
not have the financing for this, which is why they typically cannot implement innovative concepts.

Large firms, such as JP Morgan Chase; Pfizer Inc. and AT\&T address internationalize through mergers and acquisitions, but born globals cannot acquire worldwide subsidiaries because they lack the necessary resources. Thus, born globals depend on different modes of controlling assets, including network communities and hybrid structures (Oviatt \& McDougall, 1994).

Effective and efficient networking is essential to the success of born globals. Madsen and Servais (1997) introduced the idea that entrepreneurs of SMEs ought to have aggressive managers on their team for the purpose of effectively managing hybrid networks. Because born globals must overcome many challenges to establish their place in worldwide markets, they also need qualified human resource management. Madsen and Servais (1997) argued that low-cost human resources do not benefit born global SMEs; they need competent personnel, ideally with experience in the associated industry.

Moen (2002) also identified various challenges faced by born globals. After examining corporations in Norway and France, he determined that born globals are confronted by challenges in different business domains. The new challenges he identified included establishing production facilities, effective human resource management and recruitment of talented employees. 
External challenges are often associated with the initiation of exporting, and can include political situations in different nations, governmental boundaries, lack of information about enterprise and international laws, language differences and variations in business practices. These external challenges were also recognized by Oviatt and McDougall (1994).

Moen (2002) argued that a lack of brand name image in their home country is a major obstacle for born global SMEs. Unlike MNCs or other large local companies, born globals don't benefit from brand identification in their home markets. This is because they are new and their marketing is insufficient for them to establish a brand name, which makes it difficult for them to do business abroad. Also, as they need external funding for the business, born globals have proprietor-managers. If the owners get financing through external funding (i.e., from venture capitalists) it reduces their ownership, which in turn decreases their degree of control and power within the company. This can cause conflict within management, which can be a major problem for born global firms.

Market information is another challenge for born global firms. Penrose (1959) recognized two forms of knowledge: information that can be learned and transmitted to others, and knowledge that cannot be transmitted as it is acquired through personal experience. Additionally, Johnson and Vahlne (1977) stated that data gained by expertise is a core factor for rapid internationalization. Penrose (1959) and Johnson and Vahlne (1977) agree that both general knowledge and market-specific knowledge are required for a successful international business. General knowledge can be transferred between the two 
markets, whereas market-specific knowledge can only be gained by experience in that specific market. Thus, it can be concluded that born globals can have general market knowledge, but they typically lack market-specific knowledge, since they have little or no experience in the target markets.

Luostarinen and Gabrielsson (2002) studied 89 born globals in Finland to identify the entrepreneurial and managerial challenges they faced. The authors found that born globals have limited financial and managerial resources and face significant managerial challenges. They organize challenges into four groups:

i. Financial challenges

ii. Sales and marketing challenges

iii. Research and development challenges

iv. Managerial challenges

Luostarinen and Gabrielsson (2002) also determined that the above challenges are rooted in the fact that born globals lack experience and have limited resources. Other researchers have also found that these two causes are the root of the many challenges that born globals face.

Luostarinen and Gabrielsson (2002) acknowledged that they consider managerial challenges the most important obstacles facing born globals. They are the "most important" because born globals must launch a startup with a global mindset and strategy, determine and develop worldwide networks, initiate worldwide advertising and sales, and 
offer continuous product/service development, all in the very early phases of the firm. These are major managerial challenges as the company is new, lacks experience and expertise, and has limited available financial resources.

\subsection{Channel to Market}

Kenneth (1998) explains the guidelines for a channel partner, in the context of a strategic alliance relationship. He incorporates channels' expectations into company policies and procedures that work. Typically, 20 percent of the channel partners account for 80 percent of the business.

The selection of international sales channels is one of the toughest challenges for startups. It takes years for global business to increase and penetrate markets abroad. Significant amounts of money and time need to be spent to establish partners and joint ventures as well as building marketing channels.

Typically, bom globals lack financial resources. For this reason, they utilize " alternative governance structures" (Oviatt \& McDougall, 1994) and rely on hybrid structures for their distribution channels (Madsen \& Servais, 1997). However, little is known about the combination of channels they should implement as well as the characteristics of the players that should be part of these combinations. 


\subsection{Channel categories}

A channel to market is a set of interdependent organizations concerned with the process of creating services or products obtainable for use or consumption (Tybout \& Calder, 2010). Based on their challenges and the benefits they offer, channels to market are organized under the following six categories:

i) Internet

ii) Relationship with multinational

iii) Distributors (Direct sales channels)

iv) Re-sellers (Indirect channels)

v) Direct sales force; and,

vi) Referrals.

\subsubsection{Internet}

Servais, Madsen, and Rasmussen (2006) examine the worldwide growth of born-global firms and their use of the Internet as a channel to market. They conclude that born-global companies depend on the Internet more than traditional firms.

Gabrielsson and Kirpalani (2004) suggest that startups that internationalize rapidly mainly rely on two channels to market: i) the Internet and ii) a relationship with a large multinational firm where both the startup and the large firm are both dependent on the outcome. 
Gabrielsson and Gabrielsson (2010) concluded that: i) the frequency of Internet-based channel usage increases during the globalization process of the firm; ii) most firms use an Internet-based sales strategy based on a multiple-channel approach; and iii) the usage of the Internet as a channel to market is extra widespread among business-to-consumer than business-to-business firms. However, the greater usage of the Internet as a channel to market can often be explained by the digital nature of the products offered by firms, akin to software and digital services.

Born globals use the Internet as a sales channel to compensate for their lack of global expertise (Arenius, Sasi, \& Gabrielsson, 2006). Many born globals form networks and market through the Internet to overcome their paucity of resources (Moen, 2002).

Proliferation of computing units and precognition of broadband helped software companies to develop and grow globally (Rönkkö, et al., 2008). The widespread adoption and use of the Internet has opened up channels to deliver software programs simply and fast to any worldwide location. This has enabled many software companies to deliver their products and services to customers electronically (Coviello \& Munro, 1997).

\subsubsection{Relationship with multinational}

Effective channels of distribution seem to be prompted by global value chains, where the born global acts as a component or finished product supplier for a, usually multinational, corporation (Gabrielsson \& Kirpalani, 2004). Relationships with multinationals contribute positively to a startup's rapid internationalization (Sutton, 2007). A born global can partner with a community, and build and leverage relationships with its predominant customer within the network. Nonetheless, the preference seems to be for 
born globals to use the Internet as a gross sales channel, combined with a community relationship with a multinational firm (Gabrielsson \& Kirpalani, 2004, p.569). In their conceptual-analytic paper, Gabriellson and Gabriellson (2003) further stressed the significance of horizontal cooperation from inception in order for born globals to prosper and survive (i.e., both parties, the born global and its partner, are dependent on the outcome).

\subsubsection{Distributors (Direct sales channels)}

The direct channel, or field sales force, is a company-owned, company-paid organization that sells products and services directly to the end customer. It is the traditional route to market that has existed for thousands of years (Friedman, 2002).

Rolnicki (1998) states that new channels are created every year in response to new products and markets, or due to behavioral influences. The new customer-satisfying companies' organizations are often entrepreneurial in nature. They develop when entrepreneurs notice a need, see a chance to earn a living, or create a new type of channel, though many are simply an improvement on a previous channel form. However, regardless of how new the channel is, it most likely falls into one of two classes: (1) it takes ownership of the manufacturer's product, or (2) it does not take ownership. When a channel does not take ownership, the manufacturer retains control over how products are priced and where they are shipped. In exchange for this control, the manufacturer performs many tasks that an ownership channel would manage.

For example, a manufacturer might: 
- Offer return provisions

- Maintain readily available inventory

- Ensure rapid delivery

- Offer credit

- Provide emergency services

- Offer some degree of product customization

- Include packaging and special handling

- Provide technical assistance

- Maintain market information

- Offer storage space

- Process orders and billing

- Provide market sales coverage

A distributor is an industrial and consumer product company that purchase products from a source and resells them directly to an end user, or to another business in the same or a related niche (Rolnicki, 1998). For example, a distributor of high-technology products buys the products from a source and resells them to another channel member (i.e., a dealer, value-added reseller or system integrator), who, in turn, sells the products to its customers.

Dealer is another name for a reseller.

A value-added reseller performs the same functions as a reseller, but with the important exception that it also bundles or adds products and services to provide a true one-stop shop or system solution for its customers. An example is a computer shop that sells sets up and installs local area network (LAN) systems for small businesses. Friedman (2002) 
describes them as high-volume distributors who sell products in large quantities to corporate accounts, or to other distributors and resellers.

A system integrator is similar to a value-added reseller, and offers a high degree of technical knowledge about complicated, system-oriented products. For example, IBM is a system integrator that sells minicomputer and midrange computers that facilitate the work of thousands of people. Sound contracting system integrators can outfit a night club, civic auditorium or church with all the microphones, mixers and amplifiers required.

Coviello (1996) stated that an extensive network of licenses, distributors and other alliances around the world were essential to the survival of a born global.

A company's size is one of the factors influencing its strategic options, and if it is small with limited assets it should develop export methods that reduce this size disadvantage (Moen, 2000). The entry modes traditionally used at the initial stage of internationalization seem to be shifting. Hedlund and Kverneland (1985) provided evidence of accelerate internationalization. They conclude that "the establishment and growth strategies on overseas markets are changing in the direction of more direct and rapid entry modes than those implied by theories of gradual and sluggish internationalization processes."

Madsen, Rasmussen and Servais (2000) found that born globals had been fairly consistent in choosing international distributors as their main export channels. This can 
be explained by the fact that born globals usually operate only in the markets that are most important to them. Due to their limited assets, they aren't in a position to spend money on market knowledge and market infrastructure in all the markets, so they often invest in closed-market contacts in a few countries. These restrictions can drive them to use a lower commitment type of operation mode. In addition, they might not want or need the greater dedication mode of a gross sales subsidiary, since their focused market section may be too small to justify the investment.

There is an underlying assumption that born globals are coming into markets quickly due to competitive pressure. According to Kim and Hwang (1992), the higher the intensity of competition in the host market, the more corporations will favor entry modes with low resource commitments, because such markets are typically less worthwhile and do not justify heavy resource commitments. This was confirmed by Madsen, Rasmussen and Servais (2000), who state that, due to their small size and limited assets, born globals typically function in an 'arm's length' arrangement in overseas markets. They found that born globals primarily export via brokers, distributors and importers. The use of lowdedication or collaborative modes suggests that large investments are not being made, and the likelihood of being current in overseas markets is not perceived to be very high. This can enable SMEs to enter extra markets if they choose, in the event that they have been utilizing high-commitment modes. 


\subsubsection{Re-sellers (Indirect channels)}

According to Friedman (2002), an indirect channel is any intermediary between the manufacturer and the end-customer. This includes manufactures' representatives, agents, brokers, resellers, local, national and global distributors, consultants, integrators, and a variety of industry-specific partner types.

Rolnicki (1998) states that a reseller is an industrial or high-technology company that purchases a product or service either directly from a manufacturer or from a distributor, depending on the sales volume or services required by the manufacturer. The higher the potential sales volume, or the more sophisticated or technical the services required, the more likely the reseller will purchase directly from the source. Resellers that provide fewer services and garner lower sales volumes deal with a distributor in the channel, also known as a dealer.

\subsubsection{Direct sales force}

The direct sales force method involves a manufacturer employing a team to sell products or services directly to an end user, without an intermediary, distributor or reseller (Rolnicki,1998), or using representatives alone or in conjunction with a direct sales force (Research Institute of America, 1975). This channel has been growing rapidly in recent years (Friedman, 2002). Some of the major companies use representatives, since they can afford a direct sales force (Shapiro, 1977).

Previous studies highlighted an important difference between a direct sales force and independent sales representatives, with respect to their selling effectiveness and different 
capabilities to produce superior customer value (Ross et al., 2005). Dishman (1996) stated that a direct sales force may be the better option when the selling company wants to provide assistance and service to the customer base. In general, the literature on sales force control systems suggests that using a direct sales force allows greater control of salespeople, which facilitates the implementation of value-creating relational strategies (Cravens et al., 1993; Grant \& Cravens, 1996). The main argument supporting this perspective is that, since straight commission constitutes the most relevant (if not exclusive) form of payment of independent sales representatives, it encourages them to maximize immediate sales. However, they sometimes adopt hard selling techniques, at the expense of value-adding relationship selling approaches (Hawes et al., 1996).

The use of a direct sales force has a positive impact on the creation of superior customer value. Over the last decade, many authors have recommended shifting from an adversarial model to a cooperative model of interaction between buyer and seller (Wotruba, 1996). This implies moving from a model in which salespeople attempt to persuade buyers to do something that will benefit the salesperson's firm, to a win-win approach, with salespeople becoming more like customer partners (Weitz \& Bradford, 1999; Wilson, 2000), increasing their customer orientation and reducing their selling orientation (Saxe \& Weitz, 1982). This approach demonstrates that a direct sales force requires manpower, administrative and supervisory support, capital and assets (sales offices). 


\subsubsection{Referrals}

A referral channel is a special type of information channel. There are qualitatively different types of referral channels, and they must be managed by different forms of cooperative strategy (Herriott, 1992). Referrals can be seen as social contract; both buyers and sellers must perform and behave appropriately, since they have a common contact that can spread positive evaluations (Money, 2002). Some ideas for motivation factors can be found in the existing word-of-mouth literature on business to consumer (B-to-C) and business to business (B-to-B) fields. Helm (2000) has studied customer referrals and motives for recommendations. In B-to-C markets, market mavens spread word-of mouth because they feel they have a duty to advise, they enjoy advising, they want to reward the service provider, they are happy about the product, they are confirming their own choice, or they want to help the recipient of the advice (Goodey \& East, 2008). Goodey and East (2008) also mention that motivation for spreading word-of-mouth can originate from product involvement, self-involvement and self-confirmation. Word-of-mouth spreaders gain attention by having advice to give and asserting superiority over the listeners, or they are involved to provide knowledge regarding a particular topic. Walsh et al. (2004) found three main motivation categories for market maven activities: obligation to share information, pleasure in sharing information, and desire to help others.

\subsection{Channel Support Programs}

The complexity of the market offering, as well as the extent to which it must be customized and configured during the sales process, affects channel selection and the programs a firm delivers to support its channel partners (Friedman, 2002). Highly- 
customized offerings require the firm to deliver extensive configuration, design, training, support and advice to customers and channel partners throughout the sales process. As a result, complex offerings must be sold through "high-touch" channels, such as field sales representatives and value-added partners, who are able to interact with customers face-toface. Conversely, simple products that require minimal, if any, customization, training, support or advice can usually be sold through "low-touch" channels, with little or no face-to-face support and interaction. Low-touch channels can reach more customers at a lower cost.

According to Madsen and Servais (1997), born globals rely on "supplementary competences sourced from other firms. In their distribution channels they more often rely on hybrid structures (close relationships, network partners, etc.)." These methods can be used to avoid wasting time and money, and to make the born global more efficient and effective.

McDougall, Covin and Robinson (1994) state that the most vital competitive capabilities are the leveraging of resources and the ability to create higher order value with fewer resources. This has guided the creation of profitable new business space for born globals in need of sources where competitors are relatively strong. They must use international market channels to enter this new business space, and explore the resources through them. 
Kenneth (1998) identifies and defines eight channel support programs:

1. Educational: training, clinics, open houses

2. Selling: joint calls, shared compensation, factory salespeople

3. Promotional: contests, salesperson bonuses

4. Logistical: physical inventory levels, national and regional warehousing

5. Commitment: channel partners are supported by all management levels

6. Communications: advisory councils, field bulletins, newsletters, performance evaluations, electronic data, interchange

7. Financial: payment terms, credit, leasing, returns, discounts

8. Marketing: direct mail, qualified leads, exhibitions, cash on delivery, marketing plan, advertising

\subsubsection{Network and Alliances as channels to Market}

Technology startups that internationalize rapidly from inception require relationships with people and organizations in the targeted country to overcome local market barriers and explore new markets (Johanson \& Vahlne, 2003). Reputation and co-operation with people and organizations in targeted countries are needed for the purpose of internationalization (Kotha et al., 2010). Born globals also leverage the channels and networks of large companies to internationalize rapidly (Coviello \& Munro, 1997; Gabrielsson et al., 2008).

Born globals must be able to access networks to internationalize rapidly. Examining social ties independently of inter-organizational networks is important (Ellis, 2008). 
Networks are an important bridge to internationalization (Marlova, Manev, \& Gyoshev, 2010). Coviello and Munro (1995) found that the entrepreneur's network of contacts affects the internationalization strategies, new market selection and entry choices of born globals. They highlight the vital role that interpersonal ties have on alliance formation.

To overcome the key constraints of poor entry to economies of scale, lack of financial and knowledge resources and aversion to overcome challenges, Freeman et al. (2006) suggest that a startup should use strategies that focus on private network contacts, sturdy relationships with giant overseas prospects and suppliers, customer followership, use of advanced technology, and multiple modes of international entry.

Madsen and Servais (1997) suggest that "in comparison with other exporting firms, born globals more often rely on supplementary competences sourced from other firms; in their distribution channels they more often rely on hybrid structures (close relationships, partners, joint ventures etc.)".

These propositions have been supported in a number of qualitative studies. McGaughey (2007) found that portfolio entrepreneurs in Tasmania, Australia received considerable internationalization benefits from the coupling between different companies in the portfolio.

Presutti et al. (2008) examined an Italian serial entrepreneur and found that the entrepreneur's expertise from previous business facilitated the establishment and 
international success of born globals. However, hybrid structures also have their challenges. When the power balance is skewed, the larger partners can expropriate the rights of the smaller ones. Oviatt and McDougall (1994) promote constructing a network as a powerful alternative governance structure to formal contracts because networks control behavior by means of trust and moral obligation in addition to informal communication.

Networks allow the acquisition of wanted resources, exploitation of casual advantages and increase capacity to execute strategies. Networks provide a sequence of intermingled benefits to new ventures by the availability of knowledge, credibility and the creation of change of relationships (Johannisson, 2000). Fernhaber and McDougall (2005) argue that a new venture's networking capability is essential to its growth.

For technology-based born globals the position of trust and contracts are closely intertwined due to the fact that they need partners to successfully enter global markets (Blomquist et al., 2008). To born globals, trust is a relatively more important governance mechanism than it is to other companies. Born globals need to create trust rapidly with a view to establish profitable business. Madsen et al. (2000) claims that born globals heavily rely on relationships with other companies than others do.

Born globals select low commitment modes to overcome resource constraints, deal with risk, and supply specific demands for personalisation and support (Burgel \& Murray, 2000). Due to resource constrains, born globals use much less capital-intensive entry 
modes. Gabrielsson and Kirpalani (2004) suggest that in many cases multinational corporations might serve as viable channel alternatives for born globals.

A number of studies have contributed to our understanding of born globals since the publication of the influential work of Oviatt and McDougall (1994). Born globals rely on hybrid partners, network partners or alliances to achieve success.

Entrepreneurs can choose and handle the community to which they came from (Oviatt \& McDougall, 1994). In particular, evidence from examining born global software companies seems to indicate that networks may develop via a preliminary contact with a larger corporation. The contact rapidly evolves into a network of formal and casual contacts that provides the born global market information to internationalize (Coviello \& Munro, 1997; Sharma \& Blomstermo, 2003).

Oviatt and McDougall (1994) agree that hybrid forms are a distinct feature of a born global, and list them as one of four needed elements for their existence and as an essential part of Born Globals' sustainable aggressive advantage. That is additionally because network alliances are sometimes unique and really tough to imitate (Oviatt \& McDougall 1994).

\subsection{Lessons Learned}

The first lesson learned from the literature review is that, compared to traditional companies, bom globals show rapid growth and this growth is due to worldwide sales. 
The second lesson is that born globals greatly depend on the knowledge of their founding entrepreneurs. Founders play a vital role in the success of a born global.

The third lesson is that the study of born globals is at a very early stage. We know little about the channels to market and support programs that entrepreneurs, management teams and investors of born global firms use.

The fourth lesson is that born globals must manage networks and alliances in the very early stages of their life cycle. It is difficult to penetrate a new market if you don't have credibility, well established partners or a reputable brand. New markets also have obstacles, such as problems with market knowledge, policies, business cultures, and consumer behavior. Born global firms overcome these challenges by building collaboration with international partners and networks. It is impossible to develop an international business for born global firms without quality communication channels and efficient networks.

The fifth lesson is that born globals target a small portion of the international market, and provide tailored, personalized products and services that the multinationals are unable to deliver. Networking and strong international partners make them successful in markets which would be beyond their reach if they had to have their own subsidiaries there.

The sixth lesson is that born globals have flexible corporate structures to take advantage of the limited options available to them. When they pursue an international opportunity, 
they must push strongly for it. These are internal traits of born global firms that help them to be successful in the market. They deal with challenges with a combination of internal competencies, which they develop through strong partners, and networks with international alliances. 


\section{Chapter: Research Steps and Methodology}

Chapter 3 describes the method used to produce the deliverables of this research. Section 3.1 identifies the approach used to carry out this research. Section 3.2 defines the framework used to organize the research. Section 3.3 describes the unit of analysis. Section 3.4 identifies the study period. Section 3.5 describes the steps undertaken to carry to produce the four deliverables of this research.

\subsection{Research Approach}

This research is exploratory. The literature reviewed in Chapter 2 contains little information about the channels to market and support programs to partners that companies that internationalize rapidly from inception use.

Exploratory research helps make progress to subsequent phases (Mattar, 1993:80-81). Exploratory research aims to formulate research problems, develop hypotheses, increase awareness of the phenomenon that the author wishes to investigate, and help explore the possibility of practical realization of related research in real-life situations (Sellitz et al., 1959). An exploratory study is therefore a "first step" in an ongoing process of research.

The exploratory research approach aims to provide the researcher with a greater familiarity with the problem under study (Malhotra, 2001). 


\subsection{Framework Used}

Figure 1 illustrates the framework used in this research. It contains two conceptual blocks which resulted from combining the findings by Rolnicki (1998), Coviello and Munro (1997) Gabrielsson et al., (2008) and Friedman (2002). The two conceptual blocks are:
(A) Channels to market
(B) Channels support programs

In Figure 1, channels are the 'pipes' that connect a company (and its products and services) with the customers in their target market (Friedman, 2002). The conceptual framework is utilized to analyze selected variables that contribute to market channel selection and related programs. 
Figure 1. Market channels framework

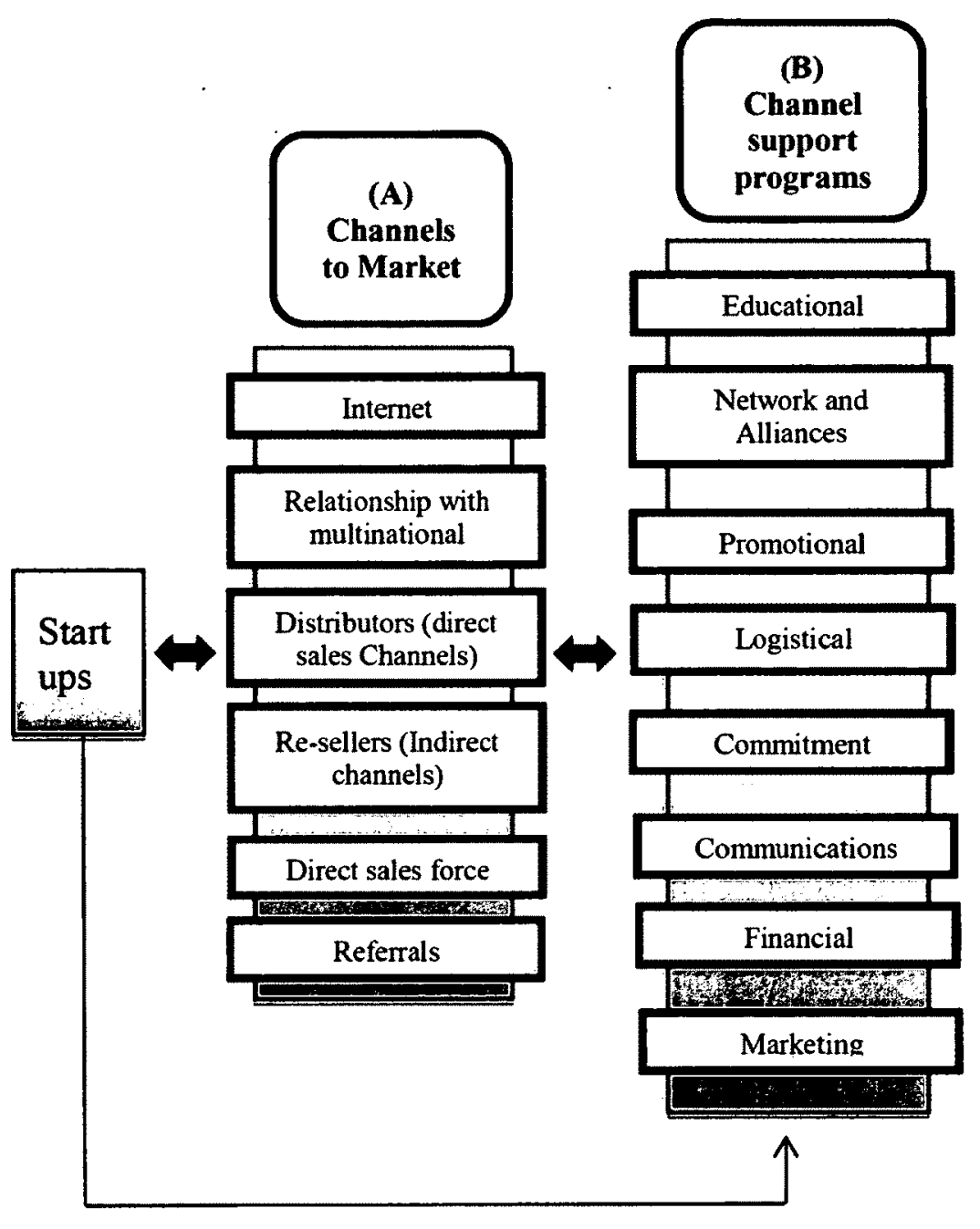

Source: Adapted and synthesized from Rolnicki and Friedman (2002), Coviello and Munro (1997) and Gabrielsson et al. (2008).

\subsection{Unit of Analysis}

The unit of analysis is the channel to market used by born global firms as well as the programs they used to support their channel partners. 


\subsection{Study Period}

The data were collected from February to October 2012. The born-global startups covered in this research were founded between 2002 and 2009, and information about their channels to market was examined over a period representing the first three years after their inception.

\subsection{Research Steps}

The objective of this research is to identify the: i) channels to market used by technology startups that internationalized rapidly from inception and ii) programs that they delivered to support their channel partners (i.e., support programs).

The four deliverables of this research are:

- Inventory of the configuration of market channels and corresponding support programs used by technology startups that internationalized rapidly from inception

- Factors that influence startups to select a specific combination of channels to market

- Features of websites that startups used to support their channels partners

- Lessons learned from carrying out this research that can be used by entrepreneurs who wish to launch and grow technology companies that internationalize rapidly from inception 
Table 1 identifies the seven steps carried out to achieve the research objective. Each of these steps is described in greater detail in the subsections that follow.

Table 1. Research steps

Step Dominant Activities Outcome

1. Define the problem

Find a practical problem on born globals that has research potential.

Attend relevant courses, reading literature, discussing potential topics with thesis supervisor.

2. Gain deep understanding of the topic
Review literature about born global and market channels.
Identified the problem of lack of knowledge on how startups internationalize using channels to market and channel partner support programs.
Defined objectives and unit of analyses.

Captured lessons from theory.

Selected exploratory case study approach.

A set of criteria.

Decide what criteria make a company fit the "born global" label. criteria and population to sample

Examine press releases and website of potential companies to include in the sample.

A list of startups to assess against the criteria.

$\begin{array}{ll}\text { 5. Collect data } & \text { Collect information about market } \\ \text { channels, partner support programs } \\ \text { and its market offers and offer types } \\ \text { for all companies that met the } \\ \text { criteria. }\end{array}$

Detailed information about 21 born-global startups.

$$
\begin{aligned}
& \text { Randomly selected six of those } 21 \\
& \text { startups for preliminary analysis. }
\end{aligned}
$$

Wrote and published an article in October 2012 issue of the Technology Innovation Management Review based on preliminary results (Yoos, 2012).
7. Detailed analysis
Categorized the market channels
Categorization market 


\subsubsection{Step 1: Define the Problem}

The selection of the research topic for this thesis arose from the desire to use my background in international trade to better understand the challenges facing businesses referred to as born globals. It was felt that my experience could add value to the research and provide me knowledge that can be used to help entrepreneurs design their channels to market.

The research problem was defined in mid-2012 after several discussions with my supervisor and my own research into the literature on born global companies.

\subsubsection{Step 2: Gain deep understanding of the topic}

After figuring out the problem that I was seeking to solve, the next step consisted in learning about born global companies and examining what researchers had to say about market channels and programs that born globals use to support their partners.

\subsubsection{Step 3: Select research methodology}

The exploratory approach to research was selected given that there is little published on the topic of interest: channels and support programs used by startups that internationalize rapidly from inception. 


\subsubsection{Step 4: Define sample criteria and population of the sample}

The output of this step was a specification of the criteria to identify born global companies and a definition of the born global population.

For the purposes of this research, the sample of interest was comprised of technologybased firms. These firms are important to both national and international innovation systems, where they serve as the vehicles for transforming basic scientific research into products needed by customers and societies. Technology companies that are born globals are important contributors to their countries' export activities and international competitiveness, potential engines for economic growth and employment opportunities.

Researchers have used various criteria to identify startups that increased their sales early and rapidly (Gabrielsson and Kirpalani, 2012). The criteria used in this thesis focus on two dimensions of internationalization: company precocity (time before first sale) and company speed (percentage of foreign sales at a given age). I was not concerned about the startups that were large-company spinoffs or joint ventures of large companies; thus, they were excluded.

Thus, to qualify for inclusion in this study group of startups should have either unique technology and/or superior design or innovative product/service, or know-how, systems or other highly specialized competence, meeting the following criteria: i) started exporting in the first 12 months after inception; ii) generated more than 50 percent of total sales through foreign customers and created more than six knowledge jobs three 
years after inception; and iii) were founded between 2002 and 2009. Moreover, none of these startups could be a large-firm spinoff or a joint venture of large firms.

All companies operated independently for three years after inception without being acquired. On top of these, to be included in the born global category, a company must have a global vision from inception. For a revision of the limits set for the categorization, see chapter 2.4 .

\subsubsection{Step 5: Collect the data}

To obtain a list of the startups to include in the sample, I used the following six steps:

Step 1:

The search utility in "Google" was used to identify web pages with keywords like: i) "born global", ii) "export award winner", or iii) phrases that combined "fast growing" or "fast export" with the words "startup", "company", and "firm". This process took two months approximately resulting on a list of companies that could meet the criteria.

\section{Step 2:}

After the list was created it was examined to filter out companies that did not fit the criteria. To decide which startups to discard, the researcher examined press releases, news articles and information posted in the companies' websites. 


\section{Step 3:}

Each website was examined to determine if the startup were founded between 2002 and 2009. Startups website sections "home", "about", "history", "frequently asked questions", "press releases", were used to draw this information.

\section{Step 4:}

After I have compiled the list of the companies identified by the web searches, for each company on the list, information about the company published on its website or in press releases, news announcements, and association journals was examined to decide whether or not the company met the criteria identified to fulfill the objective of this research. Eisenhardt (1989) suggests using theoretical sampling when selecting cases for case study research which implies that cases may be chosen to replicate previous cases or extend emergent theory. For this study, previous research did not provide a reference to select the cases using theoretical sampling as suggested by Eisenhardt (1989).

Step 5: Information on the startups identified as meeting criteria was compiled. The information included country of origin, year founded, market offer, offer type, channels to market, support programs used to support companies, and salient Web processes in the company's website.

Step 6: To be able to interpret the results of his research I organized startups into eight classes of technology business, based on how technology captures value for the firm. 


\subsubsection{Step 6: Analyze data}

I was honored when my paper was accepted for publication by the TIM Review. The article was published in the October issue of the TIM Review which had the theme of "Born Global" (Yoos, 2012). For the purpose of the article I decided to randomly select six of the startups already listed for the study. It was a great opportunity to capture early lessons learned by writing an article about my research and receive feedback from my advisor, editor and from the referees, as well as from the readers.

\subsubsection{Step 7: Detailed analyses}

The last phase sought to replicate the study published in the TIM review using all the companies in the sample.

To investigate these startups, I set out to identify the six channels to market taken from lessons learned from the literature review and list those 21 startups into a table to organize channels types, such as: Internet, Relationship with multinational, distributors (direct sales Channels), Re-sellers (Indirect channels), Direct sales force and Referrals. Having them on table will allow me to identify which channels (single or in combination) were used by the analyzed startups.

I then used the eight categories of support programs to partners of technology born globals identified by Rolnicki (1998), Coviello and Munro (1997) and Gabrielsson et al., (2008), to investigate how those startups delivered their channels partners and customers 
and how categories where organized under each channel program and under which combination they operated.

Following are the eight combined categories that I selected for the purpose of this research:

1. Educational: training, clinics, open houses

2. Networks and Alliances: Social ties, inter-firm (business) networks

3. Promotional: contests, salesperson bonuses

4. Logistical: physical inventory levels, national and regional warehousing

5. Commitment: channel partners are supported by all management levels

6. Communications: advisory councils, field bulletins, newsletters, performance evaluations, electronic data, interchange

7. Financial: payment terms, credit, leasing, returns, discounts

8. Marketing: direct mail, qualified leads, exhibitions, cash on delivery, marketing plan, advertising

The categories were rated based on frequency in programs in the category during the first three years from inception. For each of the eight categories, the table identifies the specific support programs delivered and the number of startups that delivered at least one support program within that category. 
Such approach is necessary in order to trace the specific channels and support programs, factors, processes, and specific ways, in which they affect the startups early decision and in the long run. This is the area where I see an important potential contribution. 


\section{Chapter: Results}

Chapter 4 is organized into five sections. Section 4.1 describes and categorizes the 21 technology startups that met the sample selection criteria. Section 4.2 shows the types of technology these startups operate. Section 4.3 describes channels to market used by theses startups. Section 4.4 explains the types of partner programs and website features used to support them. Section 4.5 describes the support programs the companies in the sample used to support their channels.

\subsection{Describe and categorize startups}

This section identifies the 21 startups selected for this study, and categorizes them based on geography, age, market and offer types.

Table 2 identifies the 21 technology startups that met the sample criteria. For each startup, Table 2 provides the country and year in which it was founded, and a brief description of its market offers and offer type. The sample includes startups that design, develop, and manufacture technology internally, depend on the technology supplied by others, develop software products and tools, deliver web-based specialized services, and provide custom software services.

Nine (43\%) of the 21 startups in Table 3 were founded between 2002 and 2005, and 12 (57\%) were founded between 2006 and 2009. 
Table 2. The 21 technology firms in the sample

\begin{tabular}{|c|c|c|c|c|c|}
\hline & Company & $\begin{array}{c}\text { Country of } \\
\text { Origin }\end{array}$ & $\begin{array}{c}\text { Year } \\
\text { Founded } \\
\end{array}$ & Market offer & Offer Type \\
\hline 1 & $\underline{360 \mathrm{Cities}}$ & Czech Republic & 2007 & $\begin{array}{l}\text { Panoramic photography } \\
\text { services. }\end{array}$ & $\begin{array}{l}\text { Web-based } \\
\text { service }\end{array}$ \\
\hline 2 & $\underline{\text { Airbnb }}$ & United States & 2008 & $\begin{array}{l}\text { Marketplace for unique } \\
\text { accommodations }\end{array}$ & $\begin{array}{l}\text { Web-based } \\
\text { service }\end{array}$ \\
\hline 3 & Ansarada & Australia & 2005 & Virtual data rooms & $\begin{array}{l}\text { Web-based } \\
\text { service }\end{array}$ \\
\hline 4 & Atlassian & Australia & 2002 & $\begin{array}{l}\text { Software tools for } \\
\text { programmers working on base } \\
\text { code }\end{array}$ & Software \\
\hline 5 & Canonical & United Kingdom & 2004 & $\begin{array}{l}\text { Software customization and } \\
\text { management of large groups } \\
\text { of servers and desktops. }\end{array}$ & $\begin{array}{l}\text { Software } \\
\text { services }\end{array}$ \\
\hline 6 & Conduit & Israel & 2005 & $\begin{array}{l}\text { Enables publishers and users } \\
\text { to interact via a browser. }\end{array}$ & $\begin{array}{l}\text { Web-based } \\
\text { service }\end{array}$ \\
\hline 7 & $\frac{\text { Dewak }}{\text { S.A. }}$ & Colombia & 2008 & $\begin{array}{l}\text { Custom development of help } \\
\text { desk software products }\end{array}$ & $\begin{array}{l}\text { Software } \\
\text { services }\end{array}$ \\
\hline 8 & Dropbox & United States & 2007 & $\begin{array}{l}\text { File hosting service that offers } \\
\text { cloud storage, file } \\
\text { synchronization, and client } \\
\text { software. }\end{array}$ & $\begin{array}{l}\text { Web-based } \\
\text { service }\end{array}$ \\
\hline 9 & $\begin{array}{l}\text { Eagleyard } \\
\text { Photonics }\end{array}$ & Germany & 2002 & $\begin{array}{l}\text { High-power laser diodes for } \\
\text { medical, scientific, and } \\
\text { industrial applications }\end{array}$ & $\begin{array}{l}\text { Industrial } \\
\text { products }\end{array}$ \\
\hline 10 & eToro & Cyprus & 2007 & $\begin{array}{l}\text { Marketplace to trade } \\
\text { currencies, commodities and } \\
\text { indices online in a simple, } \\
\text { transparent and enjoyable } \\
\text { way. }\end{array}$ & $\begin{array}{l}\text { Web-based } \\
\text { service }\end{array}$ \\
\hline 11 & GoodData & Czech Republic & 2007 & $\begin{array}{l}\text { On-demand business } \\
\text { intelligence dashboards. }\end{array}$ & Software \\
\hline 12 & $\underline{\text { GPEG }}$ & United Kingdom & 2005 & $\begin{array}{l}\text { Design and manufacturer of } \\
\text { displays that is bright, clear } \\
\text { and easier to use. }\end{array}$ & $\begin{array}{l}\text { Industrial } \\
\text { products }\end{array}$ \\
\hline 13 & $\begin{array}{l}\text { Griaule } \\
\text { Biometrics }\end{array}$ & Brazil & 2002 & $\begin{array}{l}\text { Software development kits to } \\
\text { develop biometric-based } \\
\text { applications }\end{array}$ & Software \\
\hline 14 & Groupon & United States & 2008 & $\begin{array}{l}\text { Provides discounted gift } \\
\text { certificates usable at local or } \\
\text { national companies. }\end{array}$ & $\begin{array}{l}\text { Web-based } \\
\text { service }\end{array}$ \\
\hline 15 & Mojang & Sweden & 2009 & Video games & Software \\
\hline
\end{tabular}




\begin{tabular}{llllll}
\hline Company & \multicolumn{1}{c}{$\begin{array}{c}\text { Country of } \\
\text { Origin }\end{array}$} & $\begin{array}{c}\text { Year } \\
\text { Founded }\end{array}$ & Market offer & Offer Type \\
\hline 16 & $\begin{array}{l}\text { Noja } \\
\text { Power }\end{array}$ & Australia & 2002 & $\begin{array}{l}\text { Low- and medium-voltage } \\
\text { technology switchgear } \\
\text { products }\end{array}$ & $\begin{array}{l}\text { Industrial } \\
\text { product }\end{array}$ \\
\hline 17 & $\frac{\text { Papaya }}{\text { Mobile }}$ & China & 2008 & Games on a social platform & $\begin{array}{l}\text { Web-based } \\
\text { service }\end{array}$ \\
\hline 18 & $\underline{\text { Sellaband }}$ & Germany & 2006 & $\begin{array}{l}\text { Crowd funding for the } \\
\text { purpose of recording } \\
\text { professional albums }\end{array}$ & $\begin{array}{l}\text { Web-based } \\
\text { service }\end{array}$ \\
\hline 19 & Sproxil & United States & 2008 & $\begin{array}{l}\text { Authentication solutions using } \\
\text { short message service for } \\
\text { mobile phones }\end{array}$ & $\begin{array}{l}\text { Web-based } \\
\text { service }\end{array}$ \\
\hline 20 & Tufin & Israel & 2005 & $\begin{array}{l}\text { Network security products and } \\
\text { solutions }\end{array}$ & $\begin{array}{l}\text { Web-based } \\
\text { service }\end{array}$ \\
\hline 21 & Zendesk & Denmark & 2007 & $\begin{array}{l}\text { Manages customer service } \\
\text { responses }\end{array}$ & $\begin{array}{l}\text { Web-based } \\
\text { service }\end{array}$ \\
\hline
\end{tabular}


Figure 2 shows that the 21 startups were founded in five of the seven continents. Of the 21 startups, nine (43\%) were founded in six European countries (Cyprus, Czech Republic, Denmark, Germany, Sweden, United Kingdom), four in the United States (19\%), three (14\%) in Australia, two (10\%) in South America, two (10\%) in Asia - the Middle East (Israel), and one (4\%) in Asia - (China).

Figure 2. Startups in the sample by region where founded from 2002 to 2009

\section{Startups in five Continents}

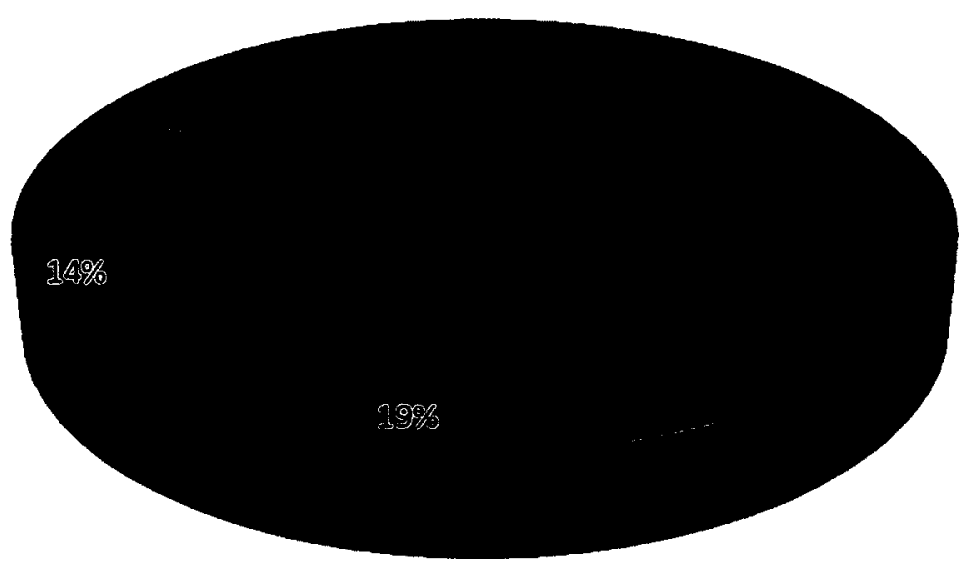

- European

- United States

australia

- Asia

- South America 
Figure 3 shows that of the 21 born global startups included in the sample, $11(52 \%)$ offered web-based services, five (24\%) developed and sold software, three (14\%) designed, developed, and manufactured industrial products, and two (10\%) delivered software services.

Figure 3. Born global startups' offer type

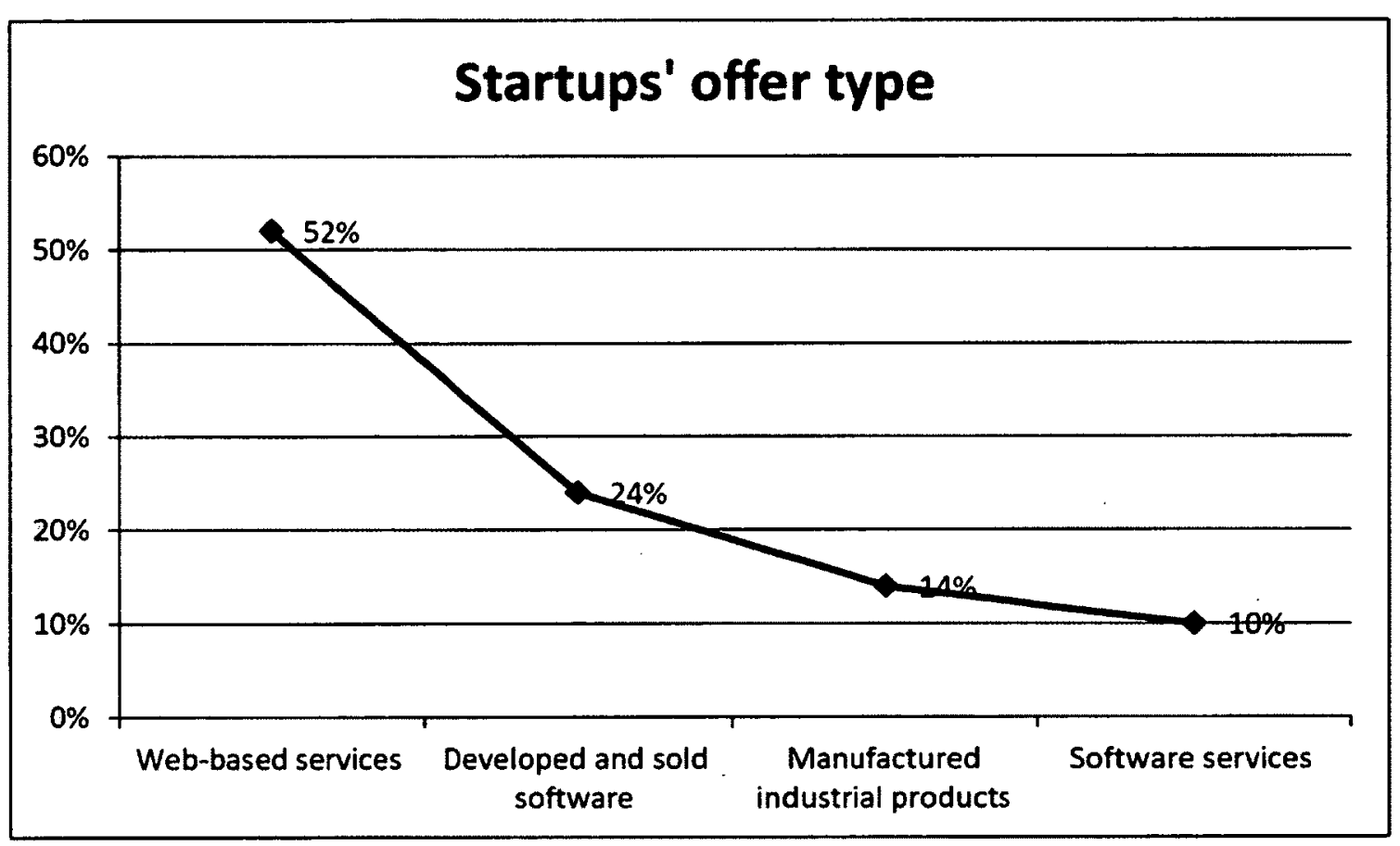




\subsection{Types of Technology}

Table 3 organizes companies in the sample based on the author's assessment of how they used technology to capture value.

Table 3. Classes of startups by use of technology to capture value

\begin{tabular}{|c|c|c|}
\hline & Classes & Startups \\
\hline 1 & $\begin{array}{l}\text { Firm's core technology comes } \\
\text { from internal } R \& D \text { or } \\
\text { university research labs }\end{array}$ & $\begin{array}{ll}- & \text { Noja Power Switchgear } \\
\text { - } & \text { Voltea } \\
\text { - } & \text { Eagleyard Photonics }\end{array}$ \\
\hline 2 & $\begin{array}{l}\text { Specialized supplier produces } \\
\text { complex engineering design in } \\
\text { collaboration with customers } \\
\text { and/or partners }\end{array}$ & $\begin{array}{ll}\text { - } & 360 \text { Cities } \\
\text { - } & \text { Canonical } \\
\text { - } & \text { Dewak } \\
\text { - } & \text { GoodData } \\
\text { - } & \text { GPEG International } \\
\text { - } & \text { Tufin } \\
\text { - } & \text { Ansarada } \\
\end{array}$ \\
\hline 3 & $\begin{array}{l}\text { Service supplier makes } \\
\text { capacity available for a fee }\end{array}$ & $\begin{array}{ll}- & \text { Dropbox } \\
\text { - } & \text { Sproxil } \\
\end{array}$ \\
\hline 4 & $\begin{array}{l}\text { Firm's technology comes from } \\
\text { external sources over which } \\
\text { the firm may have some, little } \\
\text { or no influence }\end{array}$ & Mojang \\
\hline 5 & $\begin{array}{l}\text { Firm uses Web to automate } \\
\text { manual process }\end{array}$ & Groupon \\
\hline 6 & $\begin{array}{l}\text { Firm uses Web to create new } \\
\text { ways for people to interact }\end{array}$ & $\begin{array}{ll}\text { - } & \text { Airbnb } \\
\text { - } & \text { Conduit } \\
\text { - } & \text { eToro } \\
\text { - } & \text { PapayaMobile } \\
\end{array}$ \\
\hline 7 & $\begin{array}{l}\text { Firm designs products for } \\
\text { small companies that lever the } \\
\text { Web }\end{array}$ & $\begin{array}{ll}- & \text { Zendesk } \\
\text { - } & \text { Sellaband }\end{array}$ \\
\hline 8 & $\begin{array}{l}\text { Firm designs products that } \\
\text { lever the Web for enterprises }\end{array}$ & Atlassian \\
\hline
\end{tabular}




\subsection{Channels to Market}

The channels to market used by the 21 startups examined were organized into six channel types: Internet, Relationship with multinational, Distributors (Direct sales channels), Resellers (Indirect channels), and Direct sales force and Referrals. Table 4 shows that none of the six startups combined all six channel types. It also shows that all 21 technology startups used the Internet as a channel to market; however, only five of the 21 startups used a relationship with a large multinational as a channel to market (360Cities, Ansarada, Conduit, Dewak S.A., Eagleyard Photonics and Sproxil).

Table 4. Channels to market used by twenty firms in the sample

\begin{tabular}{|c|c|c|c|c|c|c|}
\hline \multirow[b]{2}{*}{ Startups } & \multicolumn{6}{|c|}{ Channel Types } \\
\hline & $\begin{array}{l}\text { Internet } \\
\text { (Referrals / } \\
\text { Direct Sales) }\end{array}$ & $\begin{array}{l}\text { Relationship with } \\
\text { multinational }\end{array}$ & $\begin{array}{l}\text { Distributors } \\
\text { (Direct sales } \\
\text { channels) }\end{array}$ & $\begin{array}{l}\text { Re-sellers } \\
\text { (Indirect } \\
\text { channels) }\end{array}$ & $\begin{array}{l}\text { Direct sales } \\
\text { force }\end{array}$ & Referrals \\
\hline 360Cities & Direct sales & Google Earth & & & & \\
\hline & & $\begin{array}{l}\text { Couple large } \\
\text { companies but not } \\
\text { made info public }\end{array}$ & & & & \\
\hline Airbnb & Direct sales & & & & $\begin{array}{l}\text { Sales offices } \\
\text { around the } \\
\text { world }\end{array}$ & \\
\hline Ansarada & Direct sales & Taurus Marketing & & & $\begin{array}{l}\text { Sales offices } \\
\text { in Sydney } \\
\text { and London }\end{array}$ & \\
\hline Atlassian & Direct sales & & & & $\begin{array}{l}\text { Sales offices } \\
\text { around the } \\
\text { world }\end{array}$ & \\
\hline Canonical & Direct sales & & & $\begin{array}{l}\text { Around the } \\
\text { world }\end{array}$ & $\begin{array}{l}\text { Sales offices } \\
\text { around the } \\
\text { world }\end{array}$ & \\
\hline Conduit & Direct sales & Google & & & $\begin{array}{l}\text { Sales office } \\
\text { in Israel and } \\
\text { US }\end{array}$ & \\
\hline Dewak S.A & $\begin{array}{l}\text { Direct sales; } \\
\text { online forums } \\
\text { for customer } \\
\text { identification }\end{array}$ & Kayako & & & & \\
\hline
\end{tabular}




\begin{tabular}{|c|c|c|c|c|c|c|}
\hline \multirow[b]{2}{*}{ Startups } & \multicolumn{6}{|c|}{ Channel Types } \\
\hline & $\begin{array}{l}\text { Internet } \\
\text { (Referrals / } \\
\text { Direct Sales) }\end{array}$ & $\begin{array}{l}\text { Relationship with } \\
\text { multinational }\end{array}$ & $\begin{array}{l}\text { Distributors } \\
\text { (Direct sales } \\
\text { channels) }\end{array}$ & $\begin{array}{l}\text { Re-sellers } \\
\text { (Indirect } \\
\text { channels) }\end{array}$ & $\begin{array}{l}\text { Direct sales } \\
\text { force }\end{array}$ & Referrals \\
\hline Dropbox & Direct sales & & & & & $\begin{array}{l}\text { Referrals } \\
\text { (free space) }\end{array}$ \\
\hline $\begin{array}{l}\text { Eagleyard } \\
\text { Photonics }\end{array}$ & $\begin{array}{l}\text { Direct sales; } \\
\text { support for } \\
\text { local providers }\end{array}$ & & $\begin{array}{l}\text { Around the } \\
\text { world }\end{array}$ & & & \\
\hline eToro & Direct sales & & & & & $\begin{array}{l}\text { Referrals } \\
\text { (bonus) }\end{array}$ \\
\hline GoodData & Direct sales & & & & & \\
\hline GPEG & Direct sales & & & & $\begin{array}{l}\text { Sales offices } \\
\text { around the } \\
\text { world }\end{array}$ & \\
\hline $\begin{array}{l}\text { Griaule } \\
\text { Blometrics }\end{array}$ & Direct sales & & $\begin{array}{l}\text { Around the } \\
\text { world }\end{array}$ & $\begin{array}{l}\text { Around the } \\
\text { world }\end{array}$ & & \\
\hline Groupon & Direct sales & & & & $\begin{array}{l}\text { Around the } \\
\text { world }\end{array}$ & \\
\hline Mojang & Direct sales & & & & & \\
\hline $\begin{array}{l}\text { NOJA Power } \\
\text { Switchgear }\end{array}$ & $\begin{array}{l}\text { Direct sales; } \\
\text { telecom } \\
\text { support for } \\
\text { local providers }\end{array}$ & & $\begin{array}{l}\text { Around the } \\
\text { world }\end{array}$ & & $\begin{array}{l}\text { Sales offices } \\
\text { around the } \\
\text { world }\end{array}$ & \\
\hline $\begin{array}{l}\text { Papaya } \\
\text { Mobile }\end{array}$ & Direct sales & & . & & & \\
\hline Sellaband & Direct sales & & & & & \\
\hline Sproxil & $\begin{array}{l}\text { Direct sales; } \\
\text { telecom } \\
\text { support to } \\
\text { customers }\end{array}$ & IBM & & & $\begin{array}{l}\text { Sales offices } \\
\text { in Africa, } \\
\text { India, and the } \\
\text { USA }\end{array}$ & \\
\hline Tufin & $\begin{array}{l}\text { Direct sales; } \\
\text { telecom } \\
\text { support to } \\
\text { customers }\end{array}$ & & $\begin{array}{l}\text { Around the } \\
\text { world }\end{array}$ & & $\begin{array}{l}\text { Sales offices } \\
\text { in Europe, } \\
\text { Asia Pacific, } \\
\text { and North } \\
\text { America }\end{array}$ & \\
\hline Zendesk & Direct sales & & & & $\begin{array}{l}\text { Sales office } \\
\text { in Australia, } \\
\text { England and } \\
\text { Denmark }\end{array}$ & \\
\hline
\end{tabular}


Data provided in Table 4 suggests that six startups relied on configuration comprised of three channels, one of which was the Internet (Ansarada, Canonical, Coduit, Griaule Biometrics, Noja Power Switchgear, Sproxil, and Tufin). Nine startups relied on two channels, one of which was the Internet (360Cities, Airbnb, Atlassian, Dewak S.A, Drobox, eToro, GPEG, Groupon, Zendesk).

Information in Table 4 suggests that none of the six startups used distributors or re-sellers in combination with the Internet and a relationship with a multinational. Only two companies (360Cities and Dewak S.A.) relied solely on the Internet and a relationship with a large multinational as its channels to market. They were the only two startups out of the 21 shown in Table 4 that offered web base services and custom software development.

Two companies, Dropbox and eToro, used a combination of two channels, referrals and the Internet. Both of these companies offer Web based services.

Figure 4 illustrates the channel combinations used by the 21 bom globals in the sample. 
Figure 4. Channel Combinations used by Born Globals in the Sample

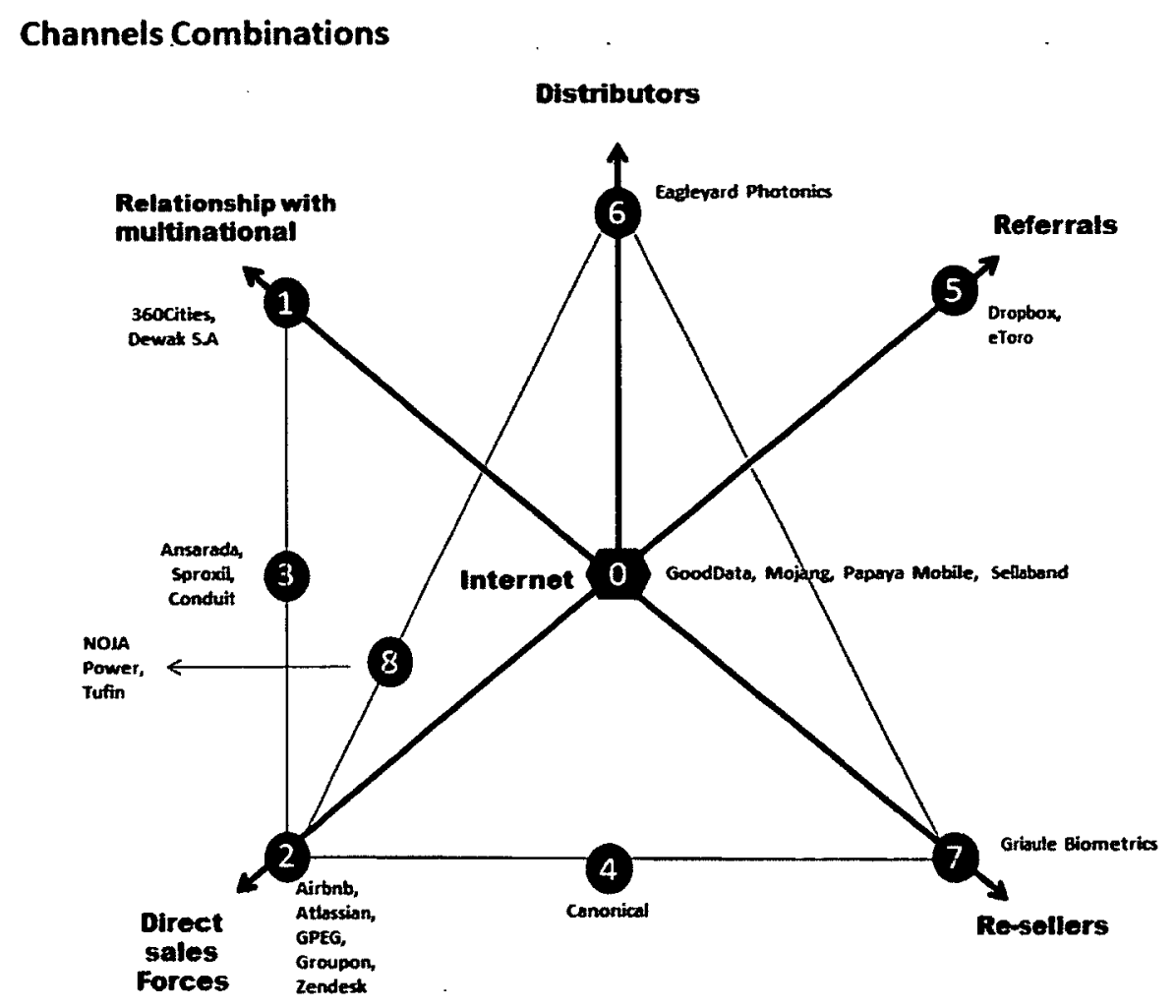

Figure 4 and Table 5 identify the eight combinations of channels to market used by the 21 startups in the sample. All startups used the Internet to internationalize, for this reason the Internet is shown at the center of Figure 4 as a zero ("0"). Figure 4 provides evidence that the Internet is an important channel to market for startups. 
Table 5. Combinations of Channels to Market Used by 21 Companies in the Sample

\begin{tabular}{|c|c|c|c|}
\hline Combinations & $\begin{array}{c}\text { Number of } \\
\text { channels } \\
\text { used }\end{array}$ & Channels & Startups \\
\hline Combination 1 & 2 & $\begin{array}{l}\text { Internet and } \\
\text { Relationship } \\
\text { with } \\
\text { Multinational }\end{array}$ & $\begin{array}{ll}> & \text { 360Cities } \\
> & \text { Dewak S.A }\end{array}$ \\
\hline Combination 2 & 2 & $\begin{array}{l}\text { Intemet and } \\
\text { Direct Sales }\end{array}$ & $\begin{array}{l}>\text { Airbnb } \\
>\text { Atlassian } \\
>\text { GPEG } \\
>\text { Groupon } \\
>\text { Zendesk }\end{array}$ \\
\hline Combination 3 & 3 & $\begin{array}{l}\text { Internet, } \\
\text { Relationship } \\
\text { with } \\
\text { Multinational } \\
\text { and Direct } \\
\text { Sales }\end{array}$ & $\begin{array}{l}>\text { Ansarada } \\
>\text { Sproxil } \\
>\text { Conduit }\end{array}$ \\
\hline Combination 4 & 3 & $\begin{array}{l}\text { Internet, Direct } \\
\text { Sales and } \\
\text { Retail }\end{array}$ & $>$ Canonical \\
\hline Combination 5 & 2 & $\begin{array}{l}\text { Internet and } \\
\text { Referrals }\end{array}$ & $\begin{array}{l}>\text { Dropbox } \\
>\text { eToro }\end{array}$ \\
\hline Combination 6 & 2 & $\begin{array}{l}\text { Internet and } \\
\text { Distributors }\end{array}$ & $>$ Eagleyard Photonics \\
\hline Combination 7 & 3 & $\begin{array}{l}\text { Internet, } \\
\text { Distributors } \\
\text { and Resale }\end{array}$ & $>$ Griaule Biometrics \\
\hline Combination 8 & 3 & $\begin{array}{l}\text { Internet, } \\
\text { Distributor and } \\
\text { Direct Sales }\end{array}$ & $\begin{array}{l}>\text { NOJA Power } \\
>\text { Tufin }\end{array}$ \\
\hline
\end{tabular}


Data in Figure 4 and Table 5 are consistent with studies that found that the Internet does not replace face-to-face sales (Gabrielsson and Gabrielsson, 2010; Moen et al., 2003).

\subsection{Partner Programs and Website Features Used to Support Them}

Table 6 indicates that of the 21 born global startups in the sample, 11 operated partner programs. Table 6 shows that a variety of features in the startups' websites were used to support partner programs.

For the purpose of this study, if a startup offers partner programs it is indicated by a link to the programs on the startup's website. The information is accessible by current startup partners, and by potential partners who are deciding if they want to partner with the startup. The information should indicate what partner programs are available, and the benefits of each. However, startups can have features of their business on their website, but nothing about partner programs. In this case, we assume that the startup does not offer partner programs or other commitments to partners, as shown in Table 6.

Table 6. Features on the websites of the 21 technology startups that supported channel partners

\begin{tabular}{|ll}
\hline \multicolumn{1}{|c|}{ Startups } & \multicolumn{1}{c}{ Features } \\
\hline 360Cities & $>$ No partners programs indicated on the Website \\
\hline Airbnb & $>\begin{array}{l}\text { Limited information in public side of the website, sign-up } \\
\text { process is required to obtain information }\end{array}$ \\
\hline Ansarada & $>$ No partners programs indicated on the Website \\
\hline
\end{tabular}




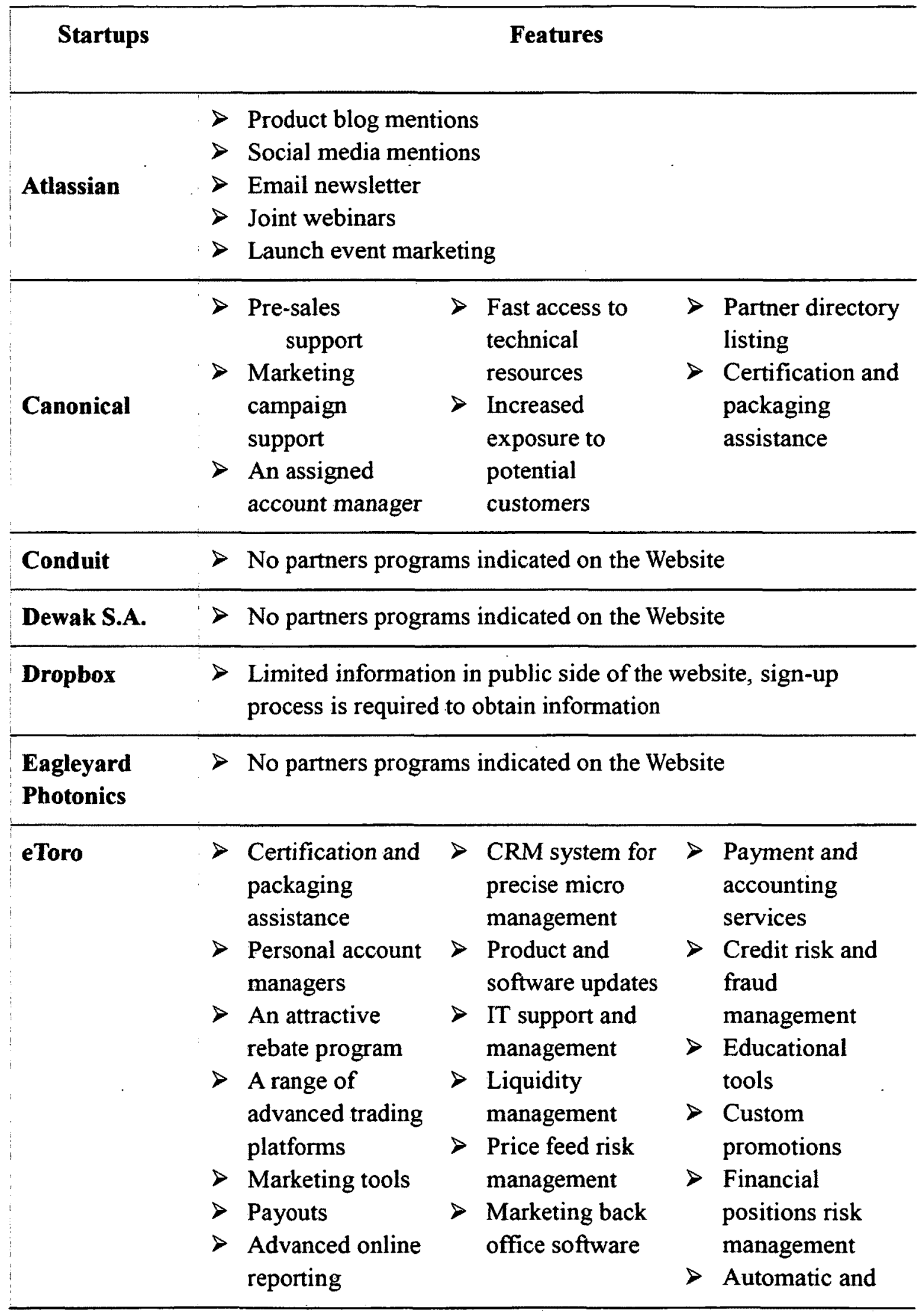


semi-automatic

order and

hedging

capabilities

\begin{tabular}{ll}
\hline GoodData & $>\begin{array}{l}\text { Provide system integrators, Implementation providers and } \\
\text { independent software vendors with technical assistance and go- } \\
\text { to-market support to deliver analytics solutions to their clients. }\end{array}$ \\
\hline GPEG & $>$ No partners programs indicated on the Website \\
\hline Griaule & $>$ R R\&D investment and technical support \\
Biometrics & $>$ Limited information in public side of the website, sign-up \\
\hline process is required to obtain information
\end{tabular}




\subsection{Channel Support Programs}

Table 7 identifies the core elements of the programs the 21 startups used to support their channel partners and customers. These core elements were organized into the following eight categories:

1. Educational: training, clinics, open houses

2. Networks and Alliances: Social ties, inter-firm (business) networks

3. Promotional: contests, salesperson bonuses

4. Logistical: physical inventory levels, national and regional warehousing

5. Commitment: channel partners are supported by all management levels

6. Communications: advisory councils, field bulletins, newsletters, performance evaluations, electronic data, interchange

7. Financial: payment terms, credit, leasing, returns, discounts

8. Marketing: direct mail, qualified leads, exhibitions, cash on delivery, marketing plan, advertising 
Table 7 identifies the core elements of the channel support collected from examining the websites of the 21 companies.

Table 7. Core elements of the Channel Support Programs

\begin{tabular}{|c|c|c|c|c|c|c|c|c|}
\hline $\begin{array}{l}\text { Core } \\
\text { Element }\end{array}$ & Education & $\begin{array}{l}\text { Network } \\
\text { and } \\
\text { Alliances }\end{array}$ & $\begin{array}{l}\text { Promotio } \\
\text { nal }\end{array}$ & Logistical & $\begin{array}{l}\text { Commit } \\
\text { ment }\end{array}$ & $\begin{array}{l}\text { Communi } \\
\text { cations }\end{array}$ & Financial & Markting \\
\hline 360Cities & $\begin{array}{l}\text { Technical } \\
\text { training } \\
\text { Access to } \\
\text { resources }\end{array}$ & $\begin{array}{l}\text { Partners } \\
\text { with } \\
\text { international } \\
\text { renowned } \\
\text { clients }\end{array}$ & $\begin{array}{l}\text { Tools to } \\
\text { locate } \\
\text { company's } \\
\text { Partner }\end{array}$ & & & $\begin{array}{l}\text { Website in } \\
\text { multiple } \\
\text { languages } \\
\text { Interact } \\
\text { using } \\
\text { Facebook, } \\
\text { Twitter, } \\
\text { Google+, } \\
\text { Blogs, Feed } \\
\text { Center, } \\
\text { Skype, } \\
\text { Live chat, } \\
\text { or video } \\
\text { conference }\end{array}$ & & $\begin{array}{l}\text { Marketplace } \\
\text { visibility } \\
\text { Product } \\
\text { blog } \\
\text { mentions } \\
\text { Social } \\
\text { media }\end{array}$ \\
\hline Airbnb & $\begin{array}{l}\text { Technical } \\
\text { training } \\
\text { Access to } \\
\text { resources } \\
\text { Support to } \\
\text { (Customer } \\
\text { Service, } \\
\text { content } \\
\text { Moderation, } \\
\text { trust \& } \\
\text { Safety } \\
\text { Team, anti- } \\
\text { fraud } \\
\text { Systems) }\end{array}$ & & $\begin{array}{l}\text { Tools to } \\
\text { locate } \\
\text { company's } \\
\text { Partner }\end{array}$ & & $\begin{array}{l}\text { The Host } \\
\text { Guarantee } \\
\text { damage up } \\
\text { to } \\
\$ 1,000,000 \text {. }\end{array}$ & $\begin{array}{l}\text { Website in } \\
\text { multiple } \\
\text { languages } \\
\text { Interact } \\
\text { using } \\
\text { Facebook, } \\
\text { Twitter, } \\
\text { Google+, } \\
\text { Blogs, Feed } \\
\text { Center, } \\
\text { Skype, } \\
\text { Live chat, } \\
\text { or video } \\
\text { conference } \\
\\
\text { Remote } \\
\text { access } \\
24 \times 7\end{array}$ & & $\begin{array}{l}\text { Marketplace } \\
\text { visibility } \\
\text { Product } \\
\text { blog } \\
\text { mentions } \\
\text { Social } \\
\text { media }\end{array}$ \\
\hline Ansarada & & & & & & $\begin{array}{l}\text { Website in } \\
\text { English } \\
\text { only } \\
\text { Interact } \\
\text { using } \\
\text { Facebook, } \\
\text { Twitter, } \\
\text { Google+, } \\
\text { Blogs, Feed } \\
\text { Center, } \\
\text { Skype, } \\
\text { Live chat, } \\
\text { or video } \\
\text { conference }\end{array}$ & & \\
\hline
\end{tabular}




\begin{tabular}{|c|c|c|c|c|c|c|c|c|}
\hline $\begin{array}{l}\text { Core } \\
\text { Element }\end{array}$ & Education & $\begin{array}{l}\text { Network } \\
\text { and } \\
\text { Alliances }\end{array}$ & $\begin{array}{l}\text { Promotio } \\
\text { nal }\end{array}$ & Logistical & $\begin{array}{l}\text { Commit } \\
\text { ment }\end{array}$ & $\begin{array}{l}\text { Communi } \\
\text { cations }\end{array}$ & Financial & Markting \\
\hline & & & . & & & $\begin{array}{l}\text { Remote } \\
\text { access } \\
24 \times 7\end{array}$ & & \\
\hline Attassian & $\begin{array}{l}\text { Technical } \\
\text { training } \\
\text { University } \\
\text { relationship } \\
\text { Certification } \\
\text { program }\end{array}$ & & $\begin{array}{l}\text { Co- } \\
\text { promotional } \\
\text { campaigns }\end{array}$ & & & $\begin{array}{l}\text { Website in } \\
\text { multiple } \\
\text { languages } \\
\text { Newsletter } \\
\text { mentions } \\
\text { Interact } \\
\text { using } \\
\text { Facebook, } \\
\text { Twitter, } \\
\text { Google+, } \\
\text { Blogs, Feed } \\
\text { Center, } \\
\text { Skype, } \\
\text { Live chat, } \\
\text { or video } \\
\text { conference }\end{array}$ & $\begin{array}{l}\text { Discounts } \\
\text { offered } \\
\text { partners }\end{array}$ & $\begin{array}{l}\text { Marketplace } \\
\text { visibility } \\
\text { Product } \\
\text { blog } \\
\text { mentions } \\
\text { Social } \\
\text { media } \\
\text { Launch } \\
\text { event }\end{array}$ \\
\hline Canonical & $\begin{array}{l}\text { Access to } \\
\text { resources } \\
\text { Certification } \\
\text { program }\end{array}$ & & $\begin{array}{l}\text { Tools to } \\
\text { locate } \\
\text { company's } \\
\text { Partner }\end{array}$ & & & $\begin{array}{l}\text { Website in } \\
\text { English } \\
\text { only }\end{array}$ & & $\begin{array}{l}\text { Marketplace } \\
\text { visibility } \\
\text { Marketing } \\
\text { campaign } \\
\text { support }\end{array}$ \\
\hline Condult & 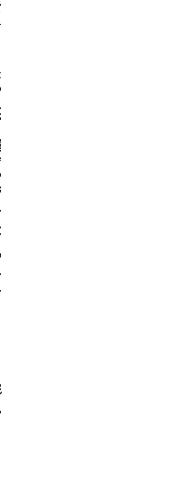 & & & & & $\begin{array}{l}\text { Interact } \\
\text { using } \\
\text { Facebook, } \\
\text { Twitter, } \\
\text { Google+, } \\
\text { Blogs, Feed } \\
\text { Center, } \\
\text { Skype, } \\
\text { Live chat, } \\
\text { or video } \\
\text { conference } \\
\text { Remote } \\
\text { access } \\
24 \times 7\end{array}$ & & \\
\hline $\begin{array}{l}\text { Dewak } \\
\text { S.A. }\end{array}$ & & $\begin{array}{l}\text { One major } \\
\text { company as } \\
\text { referral } \\
\text { Partners } \\
\text { with } \\
\text { international } \\
\text { renowned } \\
\text { clients }\end{array}$ & $\begin{array}{l}\text { Free tools } \\
\text { access } \\
\text { Free } \\
\text { licences }\end{array}$ & & & $\begin{array}{l}\text { Website in } \\
\text { multiple } \\
\text { languages } \\
\text { Interact } \\
\text { using } \\
\text { Facebook, } \\
\text { Twitter, } \\
\text { Google+, } \\
\text { Blogs, Feed } \\
\text { Center, } \\
\text { Skype, } \\
\text { Live chat, } \\
\text { or video } \\
\text { conference }\end{array}$ & & 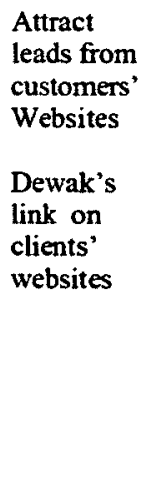 \\
\hline
\end{tabular}




\begin{tabular}{|c|c|c|c|c|c|c|c|c|}
\hline $\begin{array}{l}\text { Core } \\
\text { Element }\end{array}$ & Education & $\begin{array}{l}\text { Network } \\
\text { and } \\
\text { Alliances }\end{array}$ & $\begin{array}{l}\text { Promotio } \\
\text { nal }\end{array}$ & Logistical & $\begin{array}{l}\text { Commit } \\
\text { ment }\end{array}$ & $\begin{array}{l}\text { Communi } \\
\text { cations }\end{array}$ & Flnancial & Markting \\
\hline & . & & & & & $\begin{array}{l}\text { Meet Face } \\
\text { to Face } \\
\text { Creation of } \\
\text { product } \\
\text { reviews } \\
\text { (i.e. topic } \\
\text { thread } \\
\text { Review of } \\
\text { Dewak on } \\
\text { Kayako } \\
\text { website) to } \\
\text { enhance } \\
\text { image and } \\
\text { reliability }\end{array}$ & & \\
\hline Dropbox & & & & & & $\begin{array}{l}\text { Website in } \\
\text { multiple } \\
\text { languages } \\
\text { Interact } \\
\text { using } \\
\text { Facebook, } \\
\text { Twitter, } \\
\text { Live chat }\end{array}$ & & \\
\hline $\begin{array}{l}\text { Eagleyard } \\
\text { Photonics }\end{array}$ & & $\begin{array}{l}\text { Major } \\
\text { company as } \\
\text { referral }\end{array}$ & & & & $\begin{array}{l}\text { Interact } \\
\text { using } \\
\text { Facebook, } \\
\text { Twitter, } \\
\text { Googlet, } \\
\text { Blogs, Feed } \\
\text { Center, } \\
\text { Skype, } \\
\text { Live chat, } \\
\text { or video } \\
\text { conference }\end{array}$ & & \\
\hline eTono & $\begin{array}{l}\text { Technical } \\
\text { training }\end{array}$ & & $\begin{array}{l}\text { Tools to } \\
\text { locate } \\
\text { company's } \\
\text { Partner }\end{array}$ & & $\begin{array}{l}\text { Unique } \\
\text { approach }\end{array}$ & $\begin{array}{l}\text { Website in } \\
\text { multiple } \\
\text { languages } \\
\text { Interact } \\
\text { using } \\
\text { Facebook, } \\
\text { Twitter, } \\
\text { Google+, } \\
\text { Blogs, Feed } \\
\text { Center, } \\
\text { Skype, } \\
\text { Live chat, } \\
\text { or video } \\
\text { conference } \\
\text { Remote } \\
\text { access } \\
24 \times 7\end{array}$ & & \\
\hline GoodData & $\begin{array}{l}\text { Access to } \\
\text { resources }\end{array}$ & $\begin{array}{l}\text { Major } \\
\text { company as } \\
\text { referral }\end{array}$ & & & & $\begin{array}{l}\text { Interact } \\
\text { using } \\
\text { Facebook, }\end{array}$ & $\begin{array}{l}\text { Discounts } \\
\text { offered } \\
\text { partners }\end{array}$ & \\
\hline
\end{tabular}




\begin{tabular}{|c|c|c|c|c|c|c|c|c|}
\hline $\begin{array}{l}\text { Core } \\
\text { Element }\end{array}$ & Education & $\begin{array}{l}\text { Network } \\
\text { and } \\
\text { Alliances }\end{array}$ & $\begin{array}{l}\text { Promotio } \\
\text { nal }\end{array}$ & Logistical & $\begin{array}{l}\text { Commit } \\
\text { ment }\end{array}$ & $\begin{array}{l}\text { Communi } \\
\text { cations }\end{array}$ & Financial & Markting \\
\hline & & & & & & $\begin{array}{l}\text { Twitter, } \\
\text { Google+, } \\
\text { Blogs, Feed } \\
\text { Center; } \\
\text { Skype, } \\
\text { Live chat, } \\
\text { or video } \\
\text { conference }\end{array}$ & & \\
\hline GPEG & & & & & & $\begin{array}{l}\text { Interact } \\
\text { using } \\
\text { Twitter, } \\
\text { Skype }\end{array}$ & & \\
\hline $\begin{array}{l}\text { Griaule } \\
\text { Biometrics }\end{array}$ & $\begin{array}{l}\text { University } \\
\text { relationship } \\
\text { Access to } \\
\text { resources }\end{array}$ & 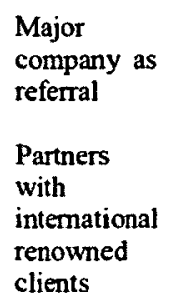 & & & & $\begin{array}{l}\text { Website in } \\
\text { multiple } \\
\text { languages }\end{array}$ & & \\
\hline Groupon & & & & & & $\begin{array}{l}\text { Website in } \\
\text { multiple } \\
\text { languages }\end{array}$ & & \\
\hline & & & & & & $\begin{array}{l}\text { Interact } \\
\text { using } \\
\text { Facebook, } \\
\text { Twitter, } \\
\text { Google+, } \\
\text { Blogs, Feed } \\
\text { Center, } \\
\text { Skype, } \\
\text { Live chat, } \\
\text { or video } \\
\text { conference }\end{array}$ & & \\
\hline Mojang & & & & . & & $\begin{array}{l}\text { Interact } \\
\text { using } \\
\text { Facebook, } \\
\text { Twitter, } \\
\text { Google+, } \\
\text { Blogs, Feed } \\
\text { Center, } \\
\text { Skype, } \\
\text { Live chat, } \\
\text { or video } \\
\text { conference }\end{array}$ & & \\
\hline $\begin{array}{l}\text { NOJA } \\
\text { Power } \\
\text { Switchgear }\end{array}$ & $\begin{array}{l}\text { Technical } \\
\text { training } \\
\text { Certification } \\
\text { program }\end{array}$ & & & & & $\begin{array}{l}\text { Interact } \\
\text { using } \\
\text { Twitter }\end{array}$ & & \\
\hline $\begin{array}{l}\text { Papaya } \\
\text { Mobile }\end{array}$ & & $\begin{array}{l}\text { Major } \\
\text { company as } \\
\text { referral }\end{array}$ & & & & $\begin{array}{l}\text { Website in } \\
\text { multiple } \\
\text { languages }\end{array}$ & & \\
\hline
\end{tabular}




\begin{tabular}{|c|c|c|c|c|c|c|c|c|}
\hline $\begin{array}{l}\text { Core } \\
\text { Element }\end{array}$ & Education & $\begin{array}{l}\text { Network } \\
\text { and } \\
\text { Alliances }\end{array}$ & $\begin{array}{l}\text { Promotio } \\
\text { nal }\end{array}$ & Logistical & $\begin{array}{l}\text { Commit } \\
\text { ment }\end{array}$ & $\begin{array}{l}\text { Communi } \\
\text { cations }\end{array}$ & Financial & Markting \\
\hline & . & & & & & $\begin{array}{l}\text { Interact } \\
\text { using } \\
\text { Facebook, } \\
\text { Twitter, } \\
\text { Blogs, Feed } \\
\text { Center }\end{array}$ & & \\
\hline Sellaband & & $\begin{array}{l}\text { Major } \\
\text { company as } \\
\text { referral }\end{array}$ & & & & $\begin{array}{l}\text { Interact } \\
\text { using } \\
\text { Facebook, } \\
\text { Twitter, } \\
\text { YouTube }\end{array}$ & & \\
\hline Sproxil & & $\begin{array}{l}\text { Four major } \\
\text { company as } \\
\text { referral } \\
\text { Partners } \\
\text { with } \\
\text { international } \\
\text { renowned } \\
\text { clients } \\
\text { Hire staff } \\
\text { from target } \\
\text { market }\end{array}$ & & & & $\begin{array}{l}\text { Interact } \\
\text { using } \\
\text { Facebook, } \\
\text { Twitter, } \\
\text { Google+, } \\
\text { Blogs, Feed } \\
\text { Center, } \\
\text { Skype, } \\
\text { Live chat, } \\
\text { or video } \\
\text { conference } \\
\text { Remote } \\
\text { access } \\
24 \times 7\end{array}$ & & \\
\hline Tufin & $\begin{array}{l}\text { Technical } \\
\text { training } \\
\text { Access to } \\
\text { resources } \\
\text { Certification } \\
\text { program }\end{array}$ & $\begin{array}{l}\text { Major } \\
\text { company as } \\
\text { referral }\end{array}$ & $\begin{array}{l}\text { Tools to } \\
\text { locate } \\
\text { company's } \\
\text { Partner }\end{array}$ & & & $\begin{array}{l}\text { Interact } \\
\text { using } \\
\text { Facebook, } \\
\text { Twitter, } \\
\text { Google+, } \\
\text { Blogs, Feed } \\
\text { Center, } \\
\text { Skype, } \\
\text { Live chat, } \\
\text { or video } \\
\text { conference }\end{array}$ & $\begin{array}{l}\text { Discounts } \\
\text { offered } \\
\text { partners }\end{array}$ & \\
\hline Zendesk & $\begin{array}{l}\text { Technical } \\
\text { training }\end{array}$ & $\begin{array}{l}\text { Major } \\
\text { company as } \\
\text { referral }\end{array}$ & . & & & $\begin{array}{l}\text { Interact } \\
\text { using } \\
\text { Facebook, } \\
\text { Twitter, } \\
\text { Google+, } \\
\text { Blogs, Feed } \\
\text { Center, } \\
\text { Skype, } \\
\text { Live chat, } \\
\text { or video } \\
\text { conference }\end{array}$ & & $\begin{array}{l}\text { Invest in } \\
\text { joint events, } \\
\text { lead } \\
\text { generation } \\
\text { campaigns } \\
\text { and other } \\
\text { marketing } \\
\text { activities) }\end{array}$ \\
\hline
\end{tabular}


The categories were rated based on the frequency in which startups delivered one or more support programs in the category during the first three years from inception. For each of the eight categories, Table 8 identifies the specific support programs delivered and the number of startups that delivered at least one support program within that category.

Table 8. Programs to support channel partners and customers delivered by 21 startups

\begin{tabular}{|c|c|c|}
\hline Category & Support Program & $\begin{array}{l}\text { Number of } \\
\text { Startups }\end{array}$ \\
\hline Communications & $\begin{array}{l}\text { - Present website in multiple languages } \\
\text { - Interact using Facebook, Twitter, Google+, Blogs, Feed } \\
\text { Center, Skype, Live chat, or video conference } \\
\text { - Meet face to face to support large projects } \\
\text { - Provide remote access to human resources } 24 \times 7 \\
\text { - Prepare product reviews }\end{array}$ & 21 \\
\hline $\begin{array}{l}\text { Networks and } \\
\text { Alliances }\end{array}$ & $\begin{array}{l}\text { - Establish a network to acquire information on local } \\
\text { markets, economic environment, regulations, competitors, } \\
\text { business, and culture } \\
\text { - Partner with internationally renowned clients } \\
\text { - Secure referrals from well-established organizations } \\
\text { - Partner with leading vendors }\end{array}$ & 10 \\
\hline Educational & $\begin{array}{l}\text { - Establish a university relationship } \\
\text { - Deliver technical training } \\
\text { - Provide access to trainers and other educational resources } \\
\text { - Deliver a certification program }\end{array}$ & 10 \\
\hline Promotional & $\begin{array}{l}\text { - Design and deliver co-promotional campaigns } \\
\text { - Provide free access to tools } \\
\text { - Provide free licenses } \\
\text { - Provide tools to locate company's partners }\end{array}$ & , \\
\hline Marketing & $\begin{array}{l}\text { - Provide marketplace visibility, mention products in blogs } \\
\text { and social media, or organize launch events } \\
\text { - Attract leads from customers' websites } \\
\text { - Place company links on clients' websites } \\
\text { - Invest in joint events, webinars, and lead-generation } \\
\text { campaigns }\end{array}$ & 6 \\
\hline
\end{tabular}


- Deliver free post-sales services

\begin{tabular}{lllc}
\hline Financial & $\bullet$ & Offer price discounts & 3 \\
\hline Commitment & $\bullet$ & Uniqueness \\
& $\bullet$ & Guarantee against damage & 2 \\
\hline Logistical & & 0 \\
\hline
\end{tabular}

Table 8 shows that all 21 startups delivered communication programs to support their channel partners and customers. Of the 21 startups, 10 delivered support programs in two categories: networks and education, and almost in the same scale 7 and 6 startups delivered support programs in the promotional and marketing category, and other close results, 3 and 2 startups delivered financial and commitment category. None of the 21 startups delivered support programs in the logistical category.

From the results above, I re-organized the 8 categories into 4 categories as follows:

$$
\begin{aligned}
& 1^{\text {st }}-\text { Communication } \\
& 2^{\text {nd }}-\text { Network and education } \\
& 3^{\text {rd }}-\text { Promotional and marketing } \\
& 4^{\text {th }}-\text { Financial and commitment }
\end{aligned}
$$




\title{
5 Chapter: Discussion
}

Chapter 5 is comprised of two sections. Section 5.1 is a discussion of the results, and Section 5.2 examines other findings of the research.

\subsection{Discussion of Results}

\subsubsection{Answering two questions}

\begin{abstract}
"What are the combinations of channel partners and support programs used by startups that internationalize rapidly from inception?"
\end{abstract}

The results shown previously in Figure 4 and Table 5 identified eight channel combinations used by the 21 startups.

Combination 1: Two of the 21 startups used the Internet and a relationship with a multinational as channel combination, which is in line with Gabrielsson and Kirpalani (2004), who suggested that startups that internationalize rapidly may rely on two channels to market: the Internet and relationships with a large multinational firm. Entrepreneurs need to consider this combination, but take into account that since only two startups used it, others should also be considered. This combination was the only one identified in the literature review, but the authors did not go into detail. All other channels were studied independent of the traditional literature to identify them as born globals activities. 
Following are the other seven of eight channel combinations as per Table 5, which are the outcomes of both this study and the gap in the born global literature.

Combination 2: Five of the 21startups used the Internet and Direct Sales as a channel combination.

Combination 4: One of the 21 startups used the Internet, Direct Sales and Retail as a channel combination.

Combination 5: Two of the 21 startups used the Internet and Referrals as a channel combination.

Combination 6: One of the 21 startups used the Internet and Distributors as a channel combination.

Combination 7: One of the 21 startups used the Internet, Distributors and Resale as a channel combination.

Combination 8: Two of the 21 startups used the Internet, Distributors and Direct Sales as a channel combination.

This research suggests that it is possible to visualize key channel combinations.

- The Internet as an isolated case: While four startups (GoodData, Mojang, Papaya Mobile and Sellaband) used only the Internet and no other channels, this was not mentioned in Table 4 since the intention was to identify all the possible channel combinations used by these startups for their rapid internationalization. However, 
it is relevant to mention these results here, as they suggest that it is possible for a born global to internationalized rapidly relying only on this channel to market. This is contrary to Gabrielsson and Kirpalani (2004), who suggest that startups that internationalize rapidly should rely on two channels to market. The Internet channel was used in all startups in combination with others, which is in line with Servais, Madsen, and Rasmussen (2006), who concluded that born global companies depend on the Internet more than traditional firms.

"What factors influence the selection of a specific combination of channels to market?"

This question is based on the preliminary results of an article published in the October 2012 issue of Technology Innovation Management Review (Yoos, 2012). The intent of the article was to understand whether the nature of a startup's business affects the combination of channels to market it uses. For example, can a startup that is not a custom software developer follow the example of Dewak S.A., and use only the Internet and a relationship with a multinational company?

The channel combinations shown in Figure 4 answer this question. Of the 21 startups, only 360Cities and Dewak S.A used channel combination (1), the Internet and a relationship with a multinational company. However, this result was not expected, as the two companies present different types of offers; one provides web-based services, and the other provides software. 
With regard to combination (3), the combination of the Internet, relationships with a multinational, and a direct sales force were used by three startups with the same webbased services offer types. The same result was found for referral channels which were selected by two startups with the same web-based services as offer types. Referral channels were explained by Herriott, 1992, Money 2002, Helm 2000, Goodey and East 2008, Goodey and East 2008 and Walsh et al. 2004.

One factor that persuades a born global to select the Internet as a unique market channel is the offer types. The results in Figure 4 show that four of the 21 startups relied only on Internet; two of them offer software, and the other two offer web-based services.

To summarize, the results showed that only three combinations were selected by startups with the same offer types: combination (0) Internet only, combination (3) Internet, relationships with a multinational and direct sales force, and combination (5) Internet and referrals. All the others startups were mixed, which does not confirm that startups can have a pattern to follow. prior to choosing their channel combinations.

This research showed that it was not possible to determine factors that influence selection of a specific combination of channels to market 


\subsection{Other findings}

Of the 21 startups in the sample, 10 used networks and alliances as a channel to market. Table 8 shows that these startups already had strong management skills; market knowledge and well-managed networks and alliances. Based on these factors, it is possible that an entrepreneur could start planning without having these channels in mind.

Of the 21 born global startups included in the sample, $11(52 \%)$ offered web-based services, five (24\%) developed and sold software, three (14\%) designed, developed, and manufactured industrial products, and two (10\%) delivered software services.

Table 3 shows the 21 startups in the sample organized into eight classes based on how they used technology to capture value. These classes are:

a) The firm's core technology comes from internal R\&D or university research labs ( 3 startups);

b) A specialized supplier that produces complex engineering design in collaboration with customers and/or partners ( 7 startups);

c) A service supplier that makes capacity available for a fee (2 startups);

d) The firm's technology comes from external sources over which the firm may have some, little or no influence (1 startup);

e) The firm uses the Web to automate manual process (1 startup);

f) The firm uses the Web to create new ways for people to interact (4 startups);

g) The firm designs products for small companies that lever the Web (2 startups); and,

h) The firm designs products that lever the Web for enterprises (1 startup).

Table 6 shows that a variety of features in the born global startups' websites were used to support partner programs. Of the 21 startups in the sample, 11 operated partner programs; 
and 10 did not. This is a key point of this research. If 10 startups did not offer partner programs and their internationalization processes were still successful, an entrepreneur with this information might be able to design channels to market plan early in the internationalization process. How many failed born global projects would this prevent?

\subsubsection{Channel to market}

The major contribution of this research is that it informs entrepreneurs who wish to launch and grow born global companies that they will need to explore eight combinations of six channels to market: i) Internet; ii) Relationships with multinationals; iii) Distributors (direct sales channels); iv) Re-sellers (indirect channels);

v) Direct sales force; and, vi) Referrals.

These six channels to market were identified by Servais, Madsen, and Rasmussen (2006), Gabrielsson and Kirpalani (2004), Gabrielsson and Gabrielsson (2010), Arenius, Sasi, and Gabrielsson (2006), Moen, (2002), Rönkkö, et al., (2008) and Coviello and Munro, (1997).

The final results show that all startups used at least one of the six channels to market for their rapid internationalization. This is in line with Kirpalani; Gabrielsson (2012), who argue that born global growth is very rapid, and thus it could require finding large channels, large partner MNEs, or other networks/alliances. 
This study addresses a gap in the born-global literature by identifying, i) the channels to market used by the 21 technology startups that internationalized rapidly and, ii) the programs that they delivered to support their channel partners (i.e. support programs).

The market channels (Tables 4 and 5): Though the 21 technology startups all used the Internet for sales, 17 of them also relied on additional channels to reach international markets, including: i) Internet, ii) relationships with multinationals, iii) distributors (direct sales channels), iv) re-sellers (indirect channels), v) direct sales force; and, vi) referrals. This suggests that born globals need to go beyond the Internet to internationalize early and rapidly.

The literature on the channels to market used by born globals is sparse and the theoretical framework is limited.

\subsubsection{Support programs}

Activities carried out by born globals were organized using the eight categories of support programs identified by Rolnicki (1998), Coviello and Munro (1997) and Gabrielsson et al., (2008).

Many entrepreneurs can take what is a great idea on paper, support it with well-prepared presentations, and secure access to grants and funding. However, then they often try to go straight to market without identifying their market channels and channel support programs. The results presented here suggest that rapid internationalization requires a variety of channels, from start to market on a number of fronts. Overlooking these key 
steps can put an entire venture at risk. As well, many entrepreneurs are tempted to internationalize rapidly using only the Internet, which can also be risky. 


\section{Chapter: Conclusion, Limitations and Future research}

\subsection{Conclusion}

This work adds to what is known about channels to market of born global firms. The research was done through an exploratory approach.

The initial aim of the study was to identify startups' channels to market. However, based on preliminary results in the article published in the October 2012 issue of the Technology Innovation Management Review (Yoos, 2012), born global startups relied on certain classes of multi-channel combinations during their rapid internationalization at inception. This increased both motivation and curiosity about research to analyze the market channels and support programs used by 21 technology startups that internationalized rapidly.

The main theoretical frameworks of born globals and market channels in the available literature were discussed, and compared to both traditional company internationalization approaches, and the processes followed by born global companies. Theoretical developments concerning market channels were reviewed, which provided a better understanding of the born global movement. Major studies that dealt specifically with the phenomenon and its differences to traditional approaches were examined, and conceptual simulations proposed for integrative models. Traditional approaches were also compared with the new reality of rapid internationalization at inception. Then, with an empirical 
focus, 21 cases in the technology industry that internationalized rapidly from inception were identified and analyzed, and discussed in the available born global literature. The country of origin of each startup was identified, and included five of the seven continents. The year in which they were founded was also determined: nine (43\%) of the 21 startups were founded between 2002 and 2005, and 12 (57\%) were founded between 2006 and 2009 (see Table 3).

It is clear that channels to market used by born globals exist; however, they are managed differently than in traditional business theory. The channels used by these 21 startups can be found in the traditional theory or in the market channels, but the study needed to focus on how born globals used and managed the channels, and adapt it to born global theory. Knowing the channels and channel support programs, and how born globals use and manage them, will contribute to born global literature, and to future research aimed at developing a born global internationalization model that can be used by all entrepreneurs. Knowing that there is a new type of company, "born global," that uses and delivers channels and support programs in a different way, means research is required to develop a detailed understanding.

The results show that the eight elements found in Tables 7 and 8 are important to the rapid internationalization of startups. They also show that based on the scale results, they are not too far apart. However, a further step can be taken when considering the results in these tables. It is possible to simplify the eight categories to four, as follows: 
Figure 5. Simplified support channel partners

\section{Communication}

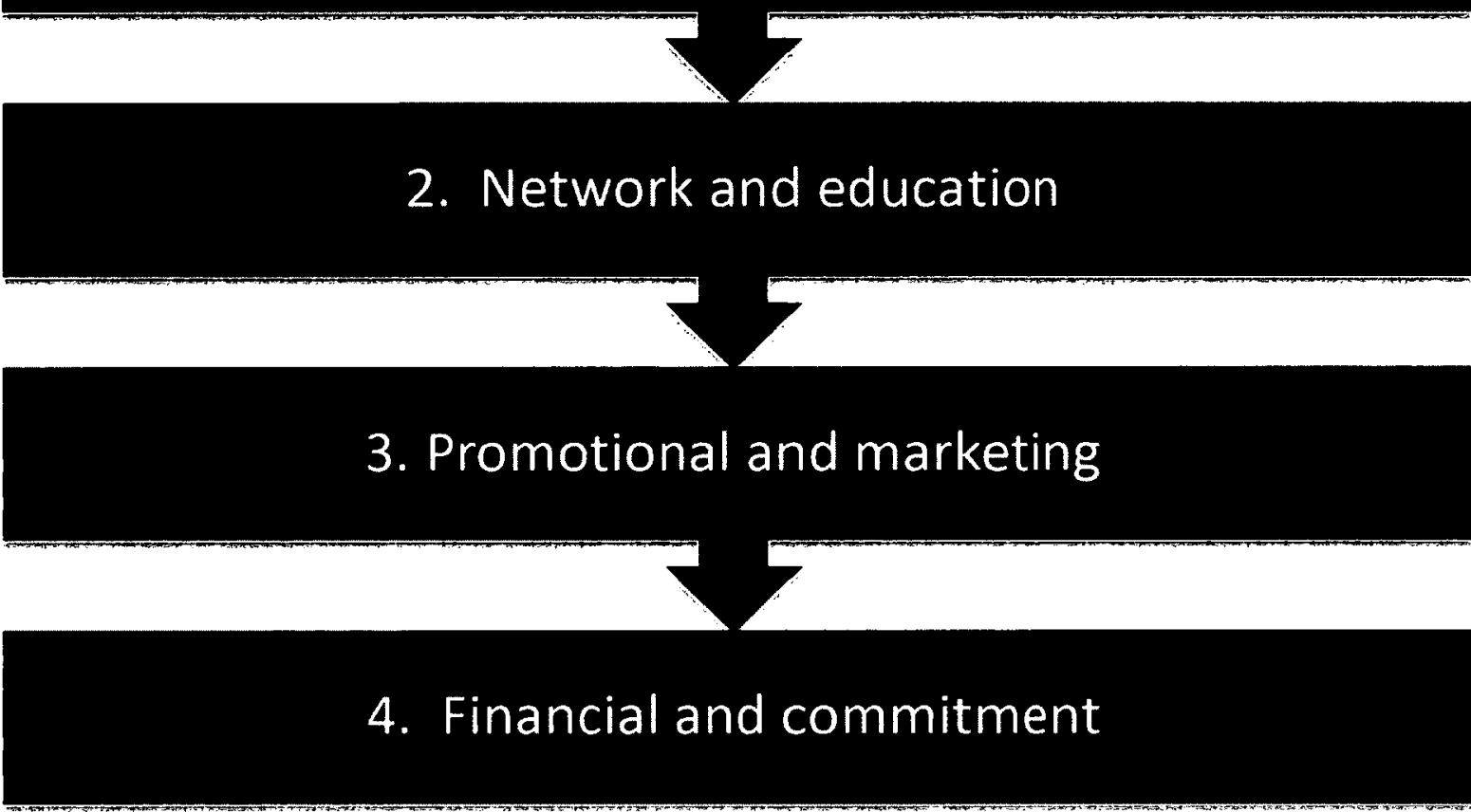

The 21 startups utilised a variety of programs to support their market channels. While all delivered communication programs, ten delivered programs focused on networks and alliances, ten delivered programs on education, seven delivered programs on promotion and six delivered programs on marketing.

It is relevant to highlight the results in Table 9 , which show that of the 21 startups, ten did not present partner programs, proving that some startups succeeded even without a specific channel program. This success could be due to entrepreneurs' skills, luck, being in the right place at the right time, or other factors. It doesn't matter how it occurred, however, as the point is if startups are succeeding even when they are disorganised, then 
there is a lot to improve on in born global theory to help and support new born global startups that internationalize by inception.

This study provides entrepreneurs access to channels to market and support programs, and demonstrates how these were used by successful startups. However, entrepreneurs should pay particular attention to the channel combinations they select, as the factors that influence this decision cannot be generalized to all startups. Most of the combinations were selected by startups with different offer types, and few combinations had the same offer types.

Internationalisation can be an excellent step for a company provided that its managers are aware of the importance of planning and preparation, and take the policies and practices of international trade into account. Otherwise, the internationalization process can potentially damage an organization's business and degrade its competitiveness.

It is my hope that this discussion will encourage research on the market channels of technology startups that internationalize rapidly from inception and their adjacent subsets, as well as more studies on born globals as they move through the phases of their evolution. They are a vital resource for innovation, and for the growth of modern economies: 


\subsection{Limitations}

This research has at least three limitations. First, this study examined data available on the startups' websites. Since there may be information that companies don't want the public to see, this should be considered an important limitation. Better and more precise results could be achieved by conducting interviews with the firms' managers.

The second limitation of this research is that it does not teach how to use the eight combinations of channels to market identified or how to create strategies to manage them.

The third limitation of this research is that it does not examine the capabilities of the team that are required to internationalize rapidly.

Fourth, this research did not examine international business theory.

\subsection{Future research}

This section suggests future research.

1. One option, directly linked to the data generated by this research, is to study some startips based only in underdeveloped countries, and others based only in developed countries, and determine if the results differ from what is found here. 
2. Another promising research approach would be to examine non-technology born globals in different industry sectors, home countries and temporal contexts, and use the information in this study to analyze their trajectory.

3. A study to describe a long term process, such as the rapid internationalization of born globals, would benefit from a longitudinal approach. Such a study would certainly generate more reliable data (Evangelista, 2005).

4. Another important issue is the performance of each market channel and its support programs. As well, the behavior of the various areas of a company during the internationalization process also requires more attention (Gabrielsson, SASI and Darling, 2004). It is a challenge to reconcile operational performance measures with the analysis of market channels of born globals that internationalized at inception.

5. It would also be interesting to study the profile of companies that failed (i.e. effectively went bankrupt), and determine the factors that contributed to this.

6. Additional relevant information could come from examining which competencies of born global firms are responsible for their success. Without knowing about the internal operations and administration, and the external competencies in all sectors, it is not currently possible to pre-determine if an idea or project could 
launch a business effectively. Born global firms need to excel in their competencies to fully succeed internationally. 


\section{References}

Andersson, S. (2000). Internationalization of the firm from an entrepreneurial perspective. International Studies of Management and Organization, 30, p.6392.

Arenius, P., Sasi, V., \& Gabrielsson, M. (2006). Rapid internationalization enabled by the Internet: The case of a knowledge intensive company. Journal of International Entrepreneurship, 3(4), 279-290.

Bell, Jim (1995). The internationalization of small computer software firms: A further challenge to "stage" theories. European Journal of Marketing, 29, (8), 60-75

Bell, J., McNaughton, R., Young, S., Crick, D. (2003) “Toward an Integrative Model of Small Firm Internationalisation", Journal of International Entrepreneurship, 1, $339-362$.

Bell, J., McNaughton, R., Young, S., 'Born-again global'firms - an extension to the 'Born global' phenomenon. Journal of International Management, 7, 173- 189. 2001. Boyd, H.W., Walker, O.C., Mullins, J. and Larre' che', J-C. (2002), Marketing Management, A Strategic Decision-Making Approach, McGraw-Hill/Irwin, Columbus, $\mathrm{OH}$.

Blomquist, K., Hurmelinna-Laukkanen, P., Nummela, N., \& Saarenketo, S. (2008). The role of trust and contracts in the internationalization of technology-intensive Born Globals. Journal of Engineering and Technology Management, 25(March), $123-135$. 
Burgel, O., \& Murray, G. C. (2000). The international market entry choices of start-up companies in high technology industries. Journal of International Marketing, $8(2), 33-49$.

Coviello, N., Munro, H.J. (1995) "Growing the Entrepreneurial Firm: Networking for International Market Development", European Journal of Marketing, 29(7):4961.

Coviello, N. 1996. Foreign Market Entry and Internationalization: The Case of Datacom Software Research. Entrepreneurship Theory \& Practice, Summer, 20(4): 95- 109.

Coviello, N., \& Munro, H. (1997). Network relationships and the internationalization process of small software firms. International Business Review, 6(4), 361-386.

Cravens, D. W. Thomas. N.I, LaForge Raymond W, Young Clifford E. Behaviour-based and outcome-based salesforce control systems. J Mark $1993 ; 57(4): 47-59$.

Dishman Paul. Exploring strategies for companies that use manufacturers' representatives as their sales force. Industry Marketing Management (1996), 25:453-61, Sept.

Eisenhardt, K. M. (1989). Building Theories From Case Study Research. Academy of Management. The Academy of Management Review; Oct 1989; 14, 4; ABI/INFORM Global pg. 532

Erramilli, K. (1990). Entry Mode Choice in Service Industries. International Marketing Review, 7 (5), 50-62.

Eugene, M. Johnson, Ray, S. House \& Carl, D. McDaniel, Jr. (1974). Readings in Contemporary Marketing. The Dryden Press, Hinsdale, Illinois, USA. 
Evangelista, F. (2005) Qualitative insights into the international new venture Creation process. Journal of International Entrepreneurship, 3, p.179-198.

Fernhaber, S. A., \& McDougall, P. P. (2005). New venture growth in international markets: The role of strategic adaption and networking capabilities. In D. A. Shephard \& J. A. Katz (Eds.), International entrepreneurship. Advances in entrepreneurship, firm emergence and growth, 8,111-136. Amsterdam: Elsevier Ltd.

Frank, G. Birgham \& Roger Gomes. (2001). Business Marketing (2nd ed.). NTC/Contemporary Publishing Group Inc. USA.

Freeman, S., Edwards, R., \& Schroder, B. (2006). How smaller Born-Global firms use networks and alliances to overcome constraints to rapid internationalization. Journal of International Marketing, 14(3), 33-63.

Friedman, G. L. (2002). Go-To-Market Strategy. Advanced Techniques And Tools For selling More Products, To More Customers, More Profitably.

Gabrielsson, M., Kirpalani, V. H. M., \& Luostarinen, R. (2002). Multiple sales channel strategies in the European PC industry. Journal of International Marketing, 10(3), 73-95.

Gabrielsson, M., \& Gabrielsson, P. (2003). Global marketing strategies of born globals and globalising internationals in the ICT field. Journal of Euromarketing, $12(3 / 4), 123-145$.

Gabrielsson, M., \& Gabrielsson, P. (2010). Internet-based sales channel strategies of born global firms. International Business Review, doi:10.1016/j.ibusrev.2010.05.001. 
Gabrielsson, M. \& Kirpalani, V. H. M. (2004). Born globals: How to reach new business space rapidly. International Business Review, 13(5), 555-571.

Gabrielsson, M. (2005). Branding strategies of born globals. Journal of International Entrepreneurship, 3, 199-222.

Gabrielsson, M., Kirpalani, V. H. M., Dimitratos, P., Solberg, C. A., \& Zucchella, A. (2008). Born globals: Propositions to help advance the theory. International Business Review, 17(4), 385-401.

Gabrielsson, M. \& Kirpalani, V.H.M. (2012). Handbook of research on born globals. ., Kirpalani, V. H. M., Dimitratos, P., Solberg, C. A., \& Zucchella, A. (2008). Born globals: propositions to help advance theory. International Business Review, 17(4), 385-401.

Goodey, C. - East, R. (2008) Testing the market maven concept. Journal of Marketing Management. 24(3-4): 265-282.

Hawes Jon M, Strong James T, Winick Bernard S. Do closing techniques diminish prospect trust? Industry Markarketing Management (1996), 25:349-60, Sept.

Herriott, S. R. (1992) Identifying and developing referral channels. Management Decision, Vol 30 No 1, pp. 4-9.

Hietala, J., Kontio, J., Jokinen, J-P., \& Pyysiäinen, J. (2004). Challenges of Software product Companies: Results of a National Survey in Finland. 10th IEEE International Symposium on Software Metrics (METRICS'04), September 14$16,2004,232-243$.

Johnson, J., \& Vahlne, J. E. (1977). The Internationalization Process of the Firm-A Model of Knowledge Development and Increasing Foreign Market Commitments. Journal of international Business Studies, 23-32. 
Johanson, J., \& Vahlne, J. - E. (2003). Business relationship learning and commitment in the internationalization process. Journal of International Entrepreneurship, $36(3), 284-303$.

Johanson, J., \& Vahlne, J.-E. (2003). Business relationship learning and commitment in the internationalization process. Journal of International Entrepreneurship, $1(1), 83-101$.

Johannisson, B. (2000). Networking and entrepreneurial growth. In D. Sexton \& H. Landstro"m (Eds.), The Blackwell handbook of entrepreneurship (pp. 368386). Oxford, UK: Blackwell.

Kenneth Rolnicki. (1998). Managing Channels of Distribution- the marketing executive's complete guide. American Management association USA.

Kim, W.C. \& Hwang, P. 1992. Global strategy and multinationals' entry mode choice. Journal of International Business Studies, 23(1): 29-53.

Knight, G. A; KIM, D. (2009). International business competence and the contemporary firm. Journal of International Business Studies, , 40, p. 255-273.

Knight, G., \& Cavusgil, T. (2005). A Taxonomy of Born-global firms. Management International Review, 4 (35), 15-35.

Kotha, S., Rindova, V. P., \& Rothaermel, F. T. (2010). Assets and actions: Firm-specific factors in the internationalization of U.S. Internet firms. Journal of International Business Studies, 32(4), 769-791.

Luostarinen, R., \& Gabrielsson, M. (2002). Globalization and Global Marketing Strategies of Born Globals in SMOPECs. Annual Conference of the European International Business Academy. Athens. 
Luostarinen, R. K., \& Gabrielsson, M. (2006). Globalization and marketing strategies of born globals in SMOPECs. Thunderbird International Business Review, 48(6), 773-801.

Luostarinen, R., \& Gabrielsson, M. (2004). Finnish perspectives of international entrepreneurship. In L.-P. Dana (Ed.), Handbook of research on international entrepreneurship, 383-403. UK: Edward Elgar Publishing.

Madsen, T. K., \& Servais, P. (1997). The internationalization of Born Globals: An evolutionary process? International Business Review, 6(6), 561-583. Madsen, T.K., Rasmussen, E., Servais, P. (2000) "Differences and similarities between born globals and other types of exporters", in Yaprak, A., Tutek,H. (ed.) Globalization, the Multinational Firm, and merging Economies (Advances in International Marketing, Vol. 10), Emerald Group Publishing Limited, 247-265.

Mattar, F. N. (1993). Pesquisa de Marketing. 1(3)

McDougall, P.P., Oviatt, B.M. (2003) "Some Fundamental Issues in International Entrepreneurship", paper submitted to Entrepreneurship Theory \& Practice.

McDougall, P. P., Covin, G. C., Robinson Jr, R. B., \& Herron, L. (1994). The effect of industry growth and strategic breath on new venture performance and strategy content. Strategic Management Journal, 15, 537-554.

McDougallL, P., Shane, S.; Oviatt, B. (1994). Explaining the formation of international new ventures: the limits of theories from international business research. Journal of Business Venturing, 9(6), 469-487.

McGaughey, S. L. (2007). Hidden ties in international new venturing: The case of portfolio entrepreneurship. Journal of World Business, 42, 307-321. 
Malhotra, N.K. Pesquisa de marketing: uma orientação aplicada. 3.ed. Porto Alegre: Bookman, 2001.

Moen, O. 2000. SMEs and International Marketing: Investigating the Differences in Export Strategy Between Firms of Different Size. Journal of Global Marketing, 13(4): 7-28

Moen, O. and Servais, P. (2002). Born Global or Gradual Global? Examining the export behavior of Small and Medium sized enterprises. Journal of International Marketing, 10, 49-72.

Money, R. B. (2002) Word-of-Mouth referral sources for buyers of international corporate financial services. Journal of World Business, 35(3), 314-329.

Oviatt, B. M., \& McDougall, P. P. (1994). Toward a theory of international new ventures. Journal of International Business Studies, 25(1), 45-64.

Penrose, E. (1959). The Theory of The Growth of The Firm. New York: Oxford University Press.

Porter, M. E. (1980). Competitive strategy: Techniques for analyzing industries and competitors. New York: The Free Press.

Presutti, M., Onetti, A., \& Odorici, V. (2008). Serial entrepreneurship and Born-Global new ventures. A case study. International Journal of Entrepreneurship Education, 6, 255-278.

Rangan, V. K. (2006). Transforming Your Go-to-Market Strategy. Harvard Business School Press. 
Rennie, M.W. (1993) “Born global”, The McKinsey Quarterly, 4, 45-52.

Rönkkö, M., Mutanen, O.-P., Koivisto, N., Ylitalo, J., Peltonen, J., Touru, A.-M., Hyrynsalmi, S., Poikonen, P., Junna, O., Ali-Yrkkö, J., Valtakoski, A., Huang, Y., \& Kantola, J. (2008). National Software Industry Survey 2008: The Finnish Software Industry in 2007. Helsinki University of Technology and University of Turku.

Research Institute of America, "When, Where, and How to Use Manufacturers' Representatives." Staff Report, 1975.

Ross William T, Dalsace Frédéric, Anderson Erin. Should you set up your own sales force or should you outsource it? Pitfalls in the standard analysis. Bus Horiz $2005 ; 48(1): 23-36$.

Selltiz, C. et al. Research methods in social relations. New York: Holt, Rinehart, 1959.

Shapiro, B. (1977). Sales Program Management Formulation and Implementation. McGraw-Hill Book Company, New York.

Sharma, D. D., \& Blomstermo, A. (2003). Internationalization process of born globals: a network view. International Business Review, 12(6): 739-753.

Saxe Robert, Weitz Barton A. The SOCO scale: a measure of the customer orientation of salespeople. Journal of Marketing Research (1982), 19(3) Aug., 343-351

Servais, P., Madsen, T. K., \& Rasmussen, E. S. (2007). Small manufacturing firms' involvement in international e-business activities. Advances in International Marketing, 17, 297-317. 
Sperling, G. Product, operation and market. Strategies of technology-intensive born globals - the case of Israeli telecommunication born globals. 2005. Helsinki School of Economics. http://hsepubl.lib.hse.fi/pdf/diss/a255.pdf.

Sutton, John (2007) "Quality, Trade and the Moving Window: The Globalization Process," The Economic Journal. 117(524): 469-498.

Tybout M. A., \&. Calder J.B (2010). Kellogg on Marketing

Walsh, G. - Gwinner, K. P. - Swanson, S., R. (2004) What makes mavens tick? Exploring of market mavens' initiation of information diffusion. Journal of Consumer Marketing, 21(2):109-122.

Weitz Barton A, Bradford Kevin D. Personal selling and sales management: a relationship marketing perspective. Journal of the Academy of Marketing Science (1999), 27(2):241-54.

Wiley, J. \& Sons, Inc (2001). Kellogg on Marketing

Willamson, R. J. (1979). Marketing for Accountants \& Managers. Heinemann, London. Wilson David T. Deep relationships: the case of the vanishing salesperson. The Journal of Personal Selling and Sales Management (2000), 20(1):53-61.

Wotruba T. (1996). The transformation of industrial selling: causes and consequences. Industry Marketing Management, 25:327-38, Sept.

Zuncchella, A. (2002). Born global versus gradually internationalizing firms: an analysis based on the Italian case. Proceedings of the 28th EIBA Annual Conference. Athens, Greece: European International Business Academy. 